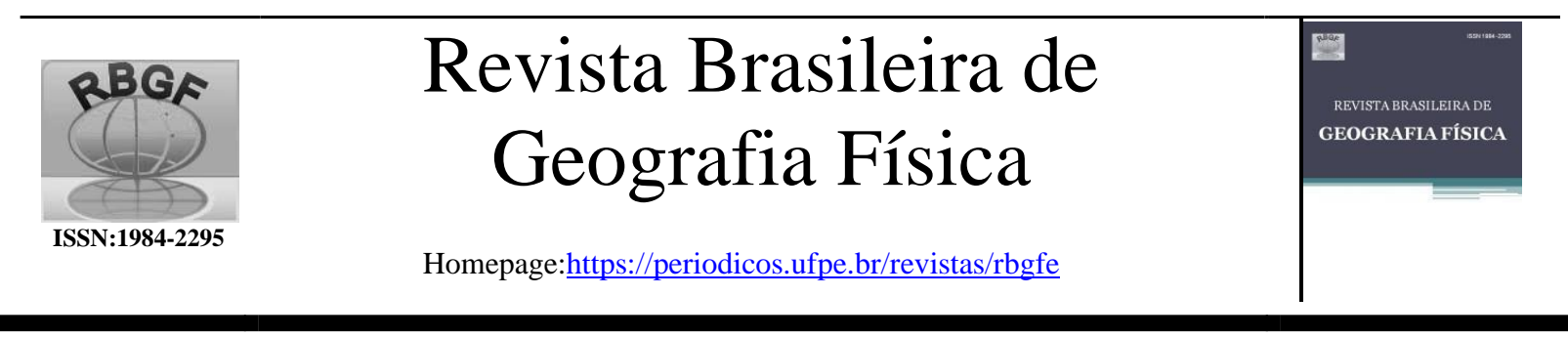

\title{
Transformações geomorfológicas, pedológicas e ambientais nos Baixos Terraços do rio Jacaré-Guaçu (sítio arqueológico Boa Esperança II, São Paulo) no Pleistoceno Tardio e Holoceno
}

\author{
Pedro Michelutti Cheliz- Departamento de Geografia, Instituto de Geociências (UNICAMP), e- \\ mail: pedro.michelutti@gmail.com (autor correspondente), Paulo César Fonseca Giannini- Instituto \\ de Geociências (USP)
}

Artigo recebido em 08/12/2019 e aceito em 29/07/2020

\begin{abstract}
R E S U M O
Com o objetivo de discutir transformações geomorfológicas, ambientais e pedológicas quaternárias da paisagem, caracterizam-se os baixos terraços e a planície aluvial do rio Jacaré-Guaçu na área entre Boa Esperança do Sul (SP) e Araraquara (SP). O conjunto de dados geomorfológicos, pedológicos, granulométricos, petrográficos, micromorfológicos, mais datações absolutas $\left(\mathrm{LOE} \mathrm{e}{ }^{14} \mathrm{C}\right)$, permitiram definir três fases de modificações ambientais. A primeira (14500-10900 anos atrás) caracteriza-se, ao menos parcialmente, por condições mais secas que as atuais e deposição de cascalheiras vinculadas a canais torrenciais efêmeros de granulometria média cinco vezes superior à do rio atual. A segunda (de 10900 até ao menos 8000 anos atrás) registra ascensão do nível de base local e do posicionamento altimétrico do canal do rio Jacaré-Guaçu de até $7 \mathrm{~m}$, intercalada com pelo menos um intervalo de estabilização do nível de base e desenvolvimento de solo hidromórfico; é marcada por aumento de umidade, deposição de sedimentos arenoargilosos e estabelecimento de um sistema fluvial perene, com meandros abandonados cuja largura é quatro vezes maior que a do canal atual. A terceira caracteriza-se pela redução do nível de base e do rio Jacaré-Guaçu em $7 \mathrm{~m}$, estabelecimento da planície de inundação atual, intensa migração rumo norte (ao menos $600 \mathrm{~m}$ ) do canal principal, e transição para padrões geomorfológicos e ambientais próximos dos vigentes atualmente (formação de meandros abandonados de larguras similares às do atual canal). Artefatos de pedra lascada mostram-se correlatos às fases I e II da formação da paisagem local, indicando que antigos grupos humanos interagiram com as modificações ambientais descritas. A disposição das peças arqueológicas líticas contribui para a definição de paleossuperfícies, formadas no âmbito das modificações de nível de base e do rio Jacaré-Guaçu.

Palavras chave: geomorfologia fluvial, mudanças climáticas, estrutura superficial da paisagem, pedologia, Quaternário
\end{abstract}

\section{Geomorphological, pedological and environmental transformations on the Low Terraces of the Jacaré-Guaçu River (Boa Esperança II archeological site, São Paulo) in Late Pleistocene and Holocene}

\begin{abstract}
A B S T R A C T
With the objective of discussing geomorphological, environmental and pedological Quaternary transformations of the landscape, the low terraces and alluvial plain of the Jacaré-Guaçu river are characterized in the area between Boa Esperança do Sul (SP) and Araraquara (SP). Geomorphological and pedological characterization, granulometric, petrographic and micromorphological analyzes, and absolute dating (OSL and ${ }^{14} \mathrm{C}$ ) were carried out to define three phases of environmental changes. The first phase (14500-10900 years ago) is characterized by, at least partially, drier conditions than the current ones and deposition of gravels linked to ephemeral torrential channels of average particle size five times coarser than those of the current river. The second one (from 10900 to at least 8000 years ago), records a rise in the local base level and the Jacaré-Guaçu river altimetric position of until $7 \mathrm{~m}$, interspersed by at least one stability interval with hydromorphic soil development; it is marked by increase in humidity, deposition of clayey sand sediments, and establishment of a perennial river system, whose abandoned meanders had width four times larger than the present channel. The third phase is characterized by the reduction of the base level and of the altimetry of JacaréGuaçu river by $7 \mathrm{~m}$, establishment of the current floodplain, intense migration towards the north (at least $600 \mathrm{~m}$ ) of the main channel, and transition to geomorphological and environmental patterns close to the current ones (formation of
\end{abstract}


abandoned meanders with similar width to the current channel). Flaked stone artifacts are correlated with phases I and II of the formation of the local landscape, indicating that ancient human groups had interactions with the mentioned environmental changes. The arrangement of lithics archeological pieces contributes to the definition of paleosurfaces developed within the changes of the base level and of the Jacaré-Guaçu river.

Keywords: fluvial geomorphology, climate change, landscape surface structure, pedology, Quaternary

\section{Introdução}

Os estudos do Quaternário voltados para discutir transformações ambientais pretéritas da paisagem têm na investigação de planícies fluviais um tema recorrente (Penteado, 1976; Celarino, 2010 e 2016; Macedo et al. 2014; Dias, 2015; Qi'na et al., 2016; Kemp et al., 2017; Barros \& Reis, 2019; Meira et al. 2019; Veneziani e Rodrigues, 2019; Lima \& Lupinacci, 2019; Oliveira et al. 2019; Hazelwood et al., 2019; Hossain et al., 2019; Pupim et al., 2019; Passos et al., 2020). Tal enfoque se justifica pelo fato de as formas de relevo, solos e sedimentos de planícies aluviais com frequência conterem evidências de padrões geomorfológicos e ambientais do passado diferentes dos atuais, sendo assim uma importante fonte de informação para compreender as transformações da paisagem e do clima ao longo do tempo (Ab`Saber, 1969). Menos comuns são as planícies fluviais que em adição aos registros paleoambientais contêm abundantes vestígios arqueológicos de ocupações humanas anteriores às das sociedades contemporâneas (Cunha et al. 2017; Peña-Monné et al. 2018). O estudo de detalhe destas planícies permite usar tanto dos atributos do meio físico natural como também dos próprios registros de ocupação humana como bases para a discussão das transformações geomorfológicas e ambientais da paisagem ao longo do tempo.

Como uma contribuição ao tema em questão, o presente trabalho busca realizar um estudo geomorfológico de detalhe em segmento da planície aluvial e dos baixos terraços do rio Jacaré-Guaçu localizado na área limítrofe entre os municípios de Araraquara e Boa Esperança do Sul, no centro do Estado de São Paulo. Este segmento de planície aluvial tem sido objeto de pesquisas arqueológicas desde 2003 (Zanettini Arqueologia, 2003; Santos, 2011, 2013) e de abordagens na interface da geomorfologia com a pedologia e a arqueologia, em escala de detalhe, desde 2010 (Cheliz, 2011, 2012a, 2012 b, 2013, 2015, 2016; Cheliz e Oliveira, 2011 e 2019; Cheliz e Ladeira, 2017; Santos e Cheliz, 2017; Cheliz et al., 2018). Um dos fatores de interesse é a presença, em meio à planície fluvial, do sítio arqueológico lítico a céu aberto Boa Esperança II (BES II - Zanettini Arqueologia, 2003). O Sítio BES II apresenta um acervo de milhares de ferramentas de pedra lascada, recolhidas de escavações nas coberturas superficiais dos baixos terraços locais, interpretadas como produtos da atividade de antigos grupos caçadores-coletores. Uma datação por luminescência opticamente estimulada (LOE), feita por Santos (2011) em horizonte arqueológico, permitiu sugerir a inserção da ocupação humana na transição Pleistoceno-Holoceno (13000-8000 anos antes do presente - AP). Simultaneamente, a contextualização inicial da geomorfologia da área (Cheliz, 2010, 2011, 2013 e 2015; Cheliz e Oliveira, 2011) sugeriu a sua correlação com mudanças ambientais e climáticas usualmente associadas pela literatura (Ab`Saber, 1998; Celarino, 2011; Souza, 2010) ao intervalo temporal entre o Pleistoceno Tardio e o Holoceno.

Neste artigo, faz-se uma compilação dos trabalhos anteriores, acrescida da apresentação e discussão de novos dados obtidos nestes Baixos Terraços, com destaque para a contextualização geomorfológica no âmbito das descrições de $\mathrm{Ab}$ 'Saber (1969). Incluem-se informações advindas de novas tradagens e unidades de escavação, associadas a análises petrográficas, macromorfológicas, micromorfológicas, granulométricas, químicas e geocronológicas $\left({ }^{14} \mathrm{C}\right.$ e LOE) em amostras de sedimentos e matéria orgânica das coberturas superficiais (Cheliz et al. 2018).

Visa-se com esses procedimentos aprofundar a discussão de que o intervalo de tempo desde a transição Pleistoceno-Holoceno foi marcado, na área, por alternâncias de condições mais secas que as atuais para outras de maior umidade, conjugadas a modificações dos padrões hidrológicos e de transformações geomorfológicas e pedológicas nos baixos terraços; busca-se também ponderar sobre como os registros arqueológicos ali presentes podem auxiliar na discussão das transformações geomorfológicas e ambientais em questão.

\section{Material e métodos}

Os procedimentos realizados no presente trabalho envolvem: levantamento bibliográfico sobre a caracterização geomorfológica e arqueológica dos Baixos Terraços do rio JacaréGuaçu associados ao sítio arqueológico Boa Esperança II; apresentação de dados inéditos de intervenções anteriores; e apresentação de novos 
dados, resultantes da pesquisa de doutorado em andamento do primeiro autor.

A contextualização geomorfológica dos Baixos Terraços foi feita a partir de mapeamento geomorfológico em escala de detalhe $(1: 25000)$ de uma área de cerca de $10 \mathrm{~km}^{2}$, contígua ao rio Jacaré-Guaçu e seus afluentes, na Bacia Sedimentar do Paraná, no trecho das Terras Baixas do Jacaré-Guaçu, conforme definidas por Cheliz (2012, 2015, 2016) - figuras 1 e 2. O mapeamento foi realizado com base na superimposição de dados advindos das cartas topográficas do IGC (2020) em escala 1:10000, descrições morfológicas de detalhe de unidades litológicas em 80 pontos de campo (Lisle, 2010) tomados entre 2010 e 2019, e levantamentos altimétricos e clinográficos feitos a partir da edição de imagens Aster (Giglioti, 2010).

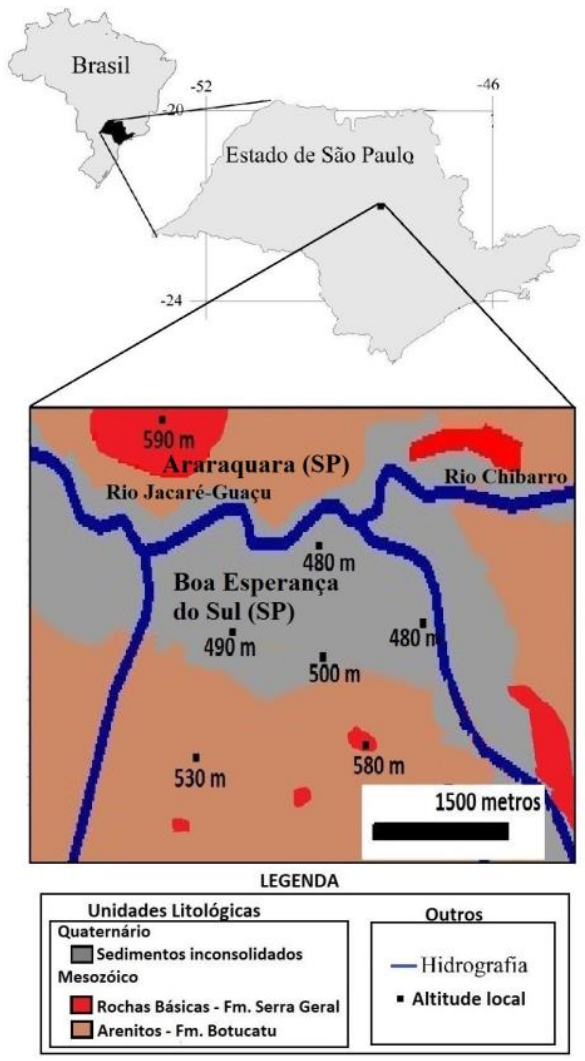

Figura 1 - Localização da área de estudo, com o rio Jacaré-Guaçu marcando o limite entre os limites de Araraquara (SP) e Boa Esperança do Sul (SP).

A coleta de dados da caracterização dos solos locais foi feita com base na descrição dos perfis de nove unidades de escavação (com comprimento e largura de $1,0 \mathrm{~m}$ e profundidade variável de 0,9 a 1,8 m), seis sondagens feitas com boca de lobo e 40 furos com uso de trado holandês - todas com escavações controladas em horizontes de $10 \mathrm{~cm}$. Adicionalmente, com o fim de melhor contextualizar os dados advindos das tradagens e unidades de escavação, foram realizados perfis topográficos simplificados, por meio de medidores de níveis, entre 2015 e 2018. As unidades de escavação (UE), sondagens e tradagens foram feitas próximas a áreas que levantamentos anteriores (Zanettini Arqueologia, 2003 e Santos, 2011) apontaram como de maior concentração de material arqueológico no sítio.

Os dados das tradagens e dos perfis topográficos simplificados foram apresentados na forma de cinco pedossequências, aprofundando caracterização efetuada nos trabalhos de Cheliz (2016) e Cheliz e Ladeira (2017).

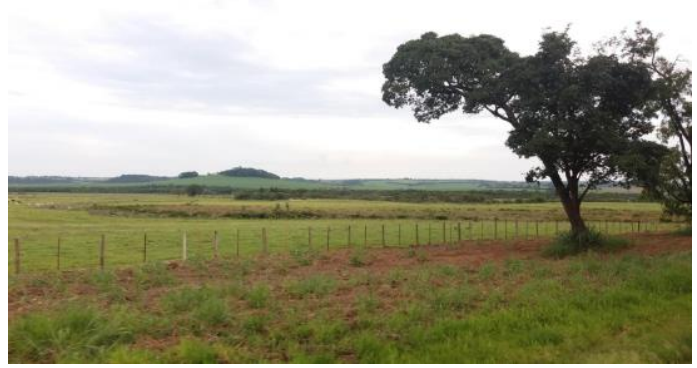

Figura 2 - Aspecto geral da área de estudo, com baixos terraços em primeiro plano.

Os dados das unidades de escavação e tradagens foram sumariados inicialmente com base na caracterização macroscópica dos principais contrastes texturais (granulação, pegajosidade e plasticidade) e visuais (sobretudo quanto a cores) dos cortes de cada uma das unidades; especificamente para uma das unidades de escavação mais recentes, já ligadas aos dados parciais da pesquisa de doutorado do primeiro autor, apresenta-se também a caracterização macromorfológica (cf. Embrapa, 2006), granulométrica, química (cf. Camargo et al., 2016), petrográfica, mineralógica e micromorfológica preliminar (cf. Castro e Cooper, 2019) de sete amostras indeformadas, bem como datações de sedimentos por LOE (análises realizadas no Laboratório de Luminescência da Universidade de Washington) e de matéria orgânica por ${ }^{14} \mathrm{C}$ (análise efetuada pelo laboratório Beta Analytic).

Ao término dos procedimentos, buscou-se comparar os dados levantados com os de trabalhos anteriores sobre transformações geomorfológicas e ambientais da área de estudo entre o Pleistoceno Tardio e o Holoceno Tardio, bem como comparar as interpretações feitas com as de estudos prévios com objetivos semelhantes efetuados em outros pontos do Estado de São Paulo e da Bacia Sedimentar do Paraná.

\section{Resultados}




\section{Contextualização geomorfológica e geológica}

Como abordado inicialmente em Cheliz (2011, 2012b, 2015 e 2016), a área de estudo insere-se na faixa de afloramentos de unidades litoestratigráficas do Grupo São Bento (notadamente os arenitos da Formação Botucatu, e as rochas máficas da Formação Serra Geral) ou de produtos de sua remobilização (colúvio) nos extremos norte e sul da área (figura 1). Ocorrem também sedimentos quaternários inconsolidados no centro e sudoeste da parcela, associados ao rio Jacaré-Guaçu, com padrão dominante meandrante (figura 3). Afloramentos rochosos mostram-se raros, sendo encontrados apenas em segmentos de declives mais íngremes; nas demais áreas, prevalecem mantos profundos de alteração das unidades litológicas da Bacia do Paraná.

Os entornos dos Baixos Terraços mostram desníveis verticais locais diminutos (dificilmente superiores a $30 \mathrm{~m}$ ) e declives suaves (raramente superiores a $10 \%$ - figura 4). Caracterizam-se pela combinação de: vertentes, nas altitudes 520-550 $\mathrm{m}$, com inclinações médias entre 4 e 10 graus, associadas a arenitos da Formação Botucatu, a rochas básicas da Formação Serra Geral ou a produtos de sua alteração ou remobilização; segmentos indistintos entre strath terraces (Bull, 1996) e vertentes suavizadas, nas altitides 490$520 \mathrm{~m}$, associados tanto a arenitos da Formação Botucatu quanto a depósitos inconsolidados arenosos; Baixos Terraços b, entre 490 e 495 m, predominantemente vinculados a depósitos inconsolidados; Baixos Terraços a, entre 485 e $490 \mathrm{~m}$, predominantemente associados a depósitos inconsolidados arenosos sob gleização; e planícies de inundação, nas altitudes $480-485 \mathrm{~m}$, contendo depósitos sedimentares inconsolidados arenoargilosos (figura 3).

Dezenas de meandros abandonados superimpõem-se às planícies de inundação e aos Baixos Terraços (Cheliz, 2013, 2016). Conforme distinção feita por Cheliz (2010, 2013 e 2016), os meandros abandonados dividem-se em dois tipos: tipo I, com largura dos paleocanais e eixos de simetria significativamente maiores do que dos atuais canais do rio Jacaré-Guaçu; e tipo II, com largura e eixos de simetria similares aos do rio Jacaré-Guaçu atual (Figura 4 e Tabela 1).

Assimetrias da drenagem e da distribuição das unidades de relevo marcam a parcela delimitada. Realça-se a diferença de largura das planícies de inundação contíguas aos trechos do rio Jacaré-Guaçu com direção NW-SE (mais estreita), em comparação com os trechos W-E (mais ampla) - figura 5 e tabela 2.
Simultaneamente, evidencia-se o nítido deslocamento do canal do rio Jacaré-Guaçu rumo a sua margem direita (norte), cujas planícies de inundação apresentam extensões em planta até cinco vezes menores que na margem esquerda (figura 5 e tabela 2) - como já observado por Cheliz (2013, 2016).

Com frequência, o rio Jacaré-Guaçu secciona diretamente terraços intermediários e vertentes, suavizadas ou não, em sua margem direita, mas não na margem oposta - como previamente observado por Cheliz (2013 e 2016). Simultaneamente, as vertentes vizinhas à margem direita do canal principal mostram-se significativamente mais íngremes do que as da margem esquerda (figura 3 ).

\section{Pedossequências}

Um segmento dos Baixos Terraços à margem esquerda, melhor preservados e associados ao sítio arqueológico Boa Esperança II, foi tomado para a realização de pedossequências.

Os perfis topográficos correlatos às pedossequências I, II, III, IV e V abrangem os Baixos Terraços a em traçados perpendiculares ao limite com as planícies de inundação a norte e oeste, e um meandro abandonado do tipo I situado no sul (figuras 6 e 7).

As variações altimétricas e clinográficas das pedossequências evidenciam um segmento mais alto, com declives relativamente suaves (Baixo Terraço 1a), e uma faixa de transição com as planícies de inundação, onde os desníveis verticais e inclinações são mais expressivos (Baixo Terraço 2a) - figuras 6 e 7.

A maior parte das tradagens das pedossequências (figura 7) aponta solos com granulação areno-argilosa ou arenosa, sendo que a presença de argila orgânica confere alta pegajosidade nas sondagens mais próximas das planícies de inundação. São os horizontes A e C que se apresentam com maior extensão horizontal e vertical. O Horizonte A é caracterizado por cores que se alternam usualmente entre 7,5 YR 4/2 e 7,5 YR 5/4 na Carta Munsell; ele possui caráter areno-argiloso ou arenoso, pouco plástico e pouco pegajoso. O Horizonte $\mathrm{C}$, por sua vez, mostra cores que se alternam ao longo dos perfis verticais predominantemente entre 7,5 YR 5,5/6 a 7,5 YR $7 / 6$, permutando segmentos pouco plásticos e pouco pegajosos, com outros de caráter ligeiramente plástico e ligeiramente pegajoso (em geral, presentes quando próximos ou abaixo do nível freático), ambos com granulação arenoargilosa ou 


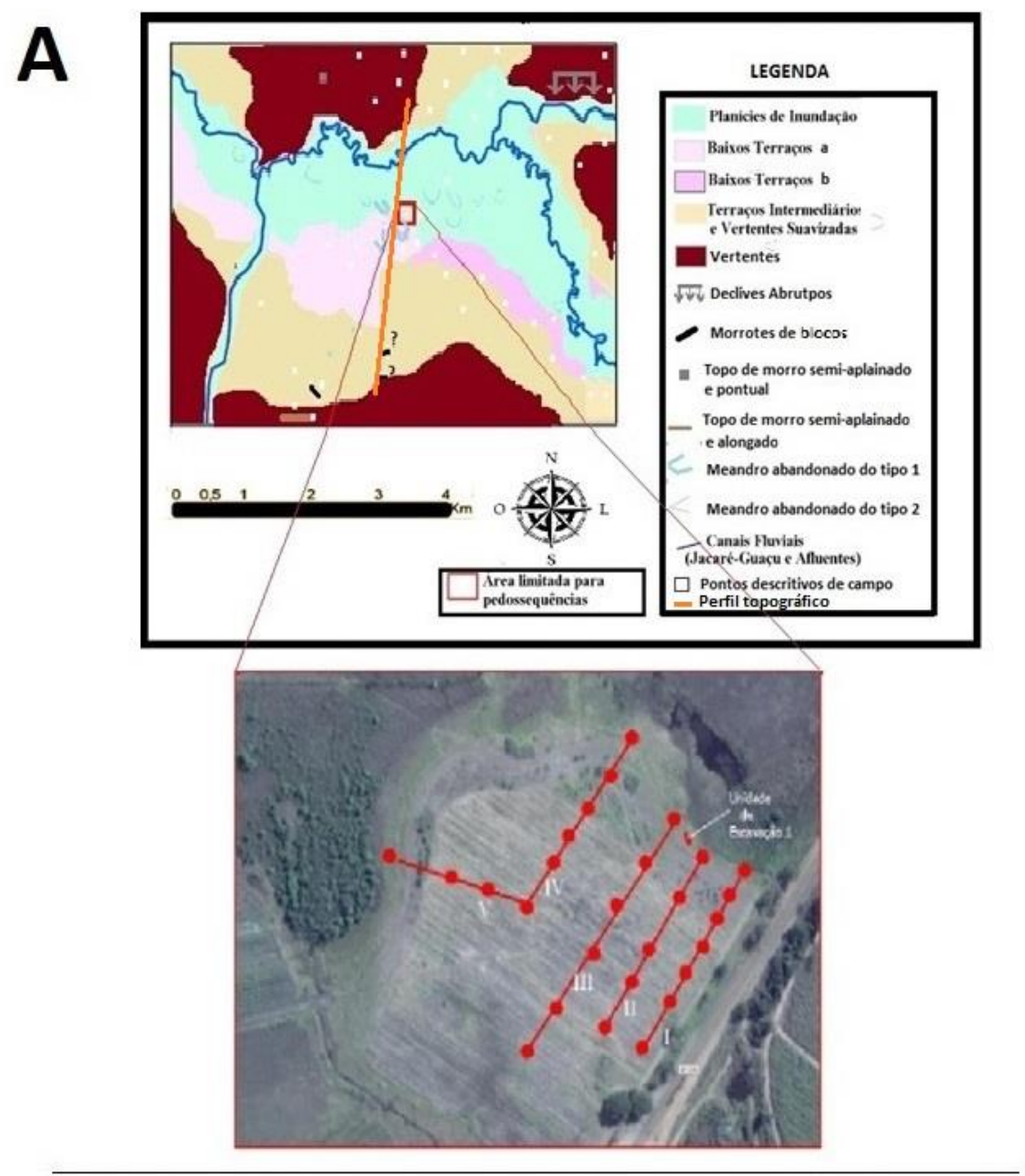

B

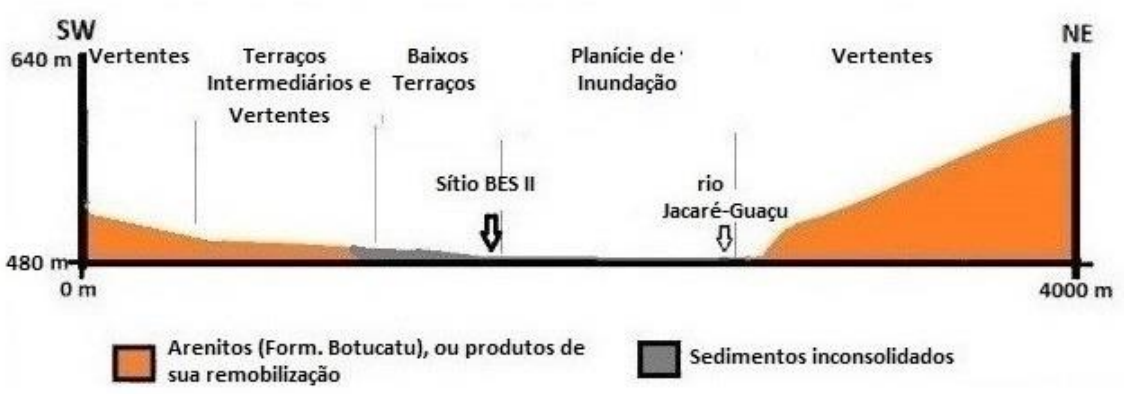

Figura 3 - A: Mapa de unidades morfológicas, com realce para segmento da área em que se concentraram as unidades de escavação, tradagens e sondagens; B: perfil mostrando associação de atributos topográficos com as unidades litoestratigráficas, cujo traçado é representado pela linha alaranjada ("perfil") no mapa da figura A. 

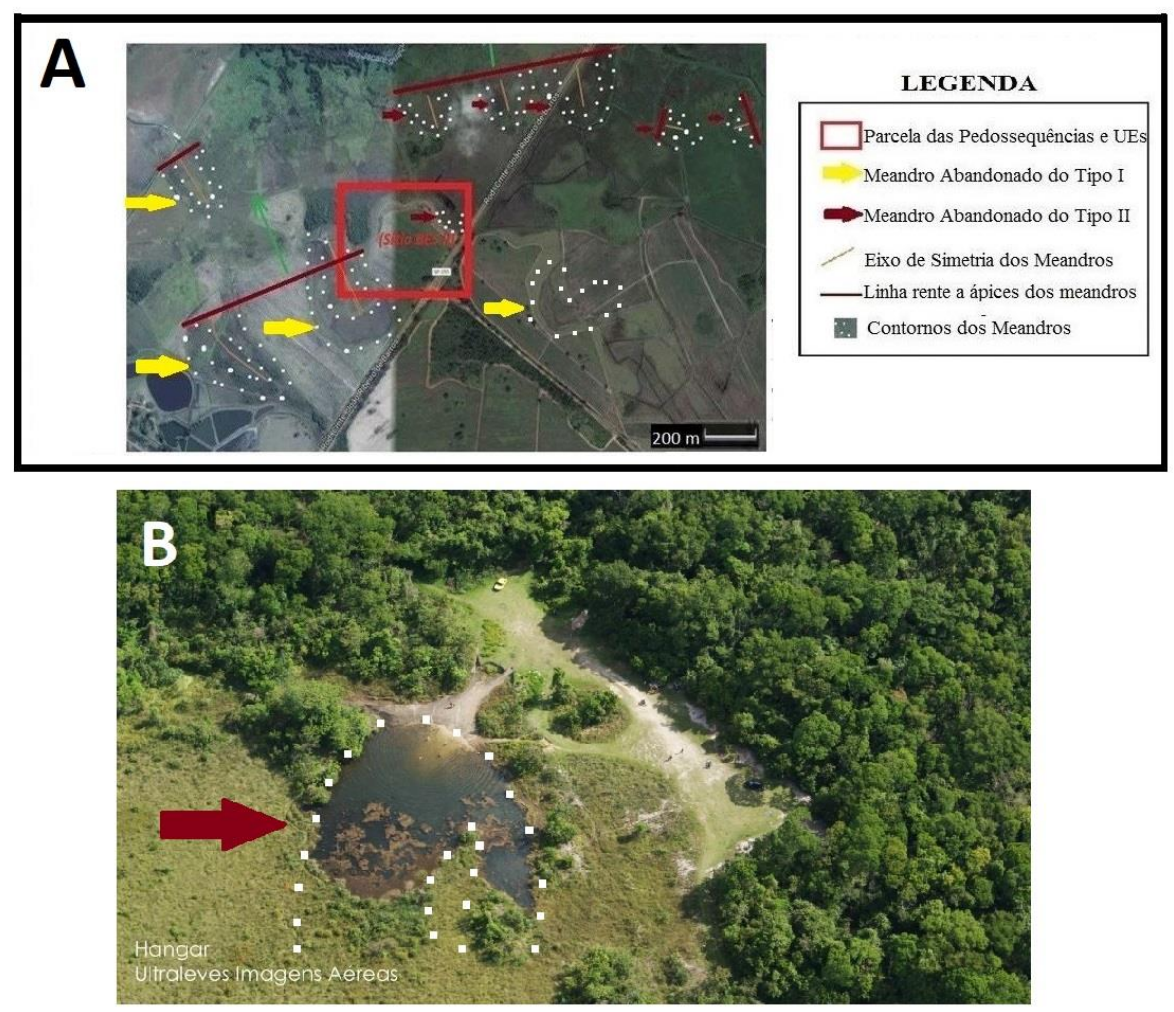

Figura 4 - A: Realce de alguns dos meandros abandonados nas terras baixas do rio Jacaré-Guaçu próximos do sítio BES II, destacados a partir de imagem do World View, disponibilizada pelo aplicativo Arcgis, B: realce de um dos meandros abandonados, em fotografia realizada a partir de ultraleve pelo aviador André Amaral.

Tabela 1 - Atributos morfológicos e direcionais essenciais dos meandros abandonados

\begin{tabular}{|c|c|c|c|}
\hline Tipo de meandro & $\begin{array}{c}\text { Direção predominante do } \\
\text { eixo de simetria }\end{array}$ & $\begin{array}{c}\text { Largura em planta } \\
\text { média do paleocanal }(\mathrm{m})\end{array}$ & $\begin{array}{c}\text { Extensão média em planta do } \\
\text { eixo de simetria }(\mathrm{m})\end{array}$ \\
\hline I & N30W & 80 & 300 \\
\hline II & N20W, N30W, W-E & 20 & 70 \\
\hline
\end{tabular}

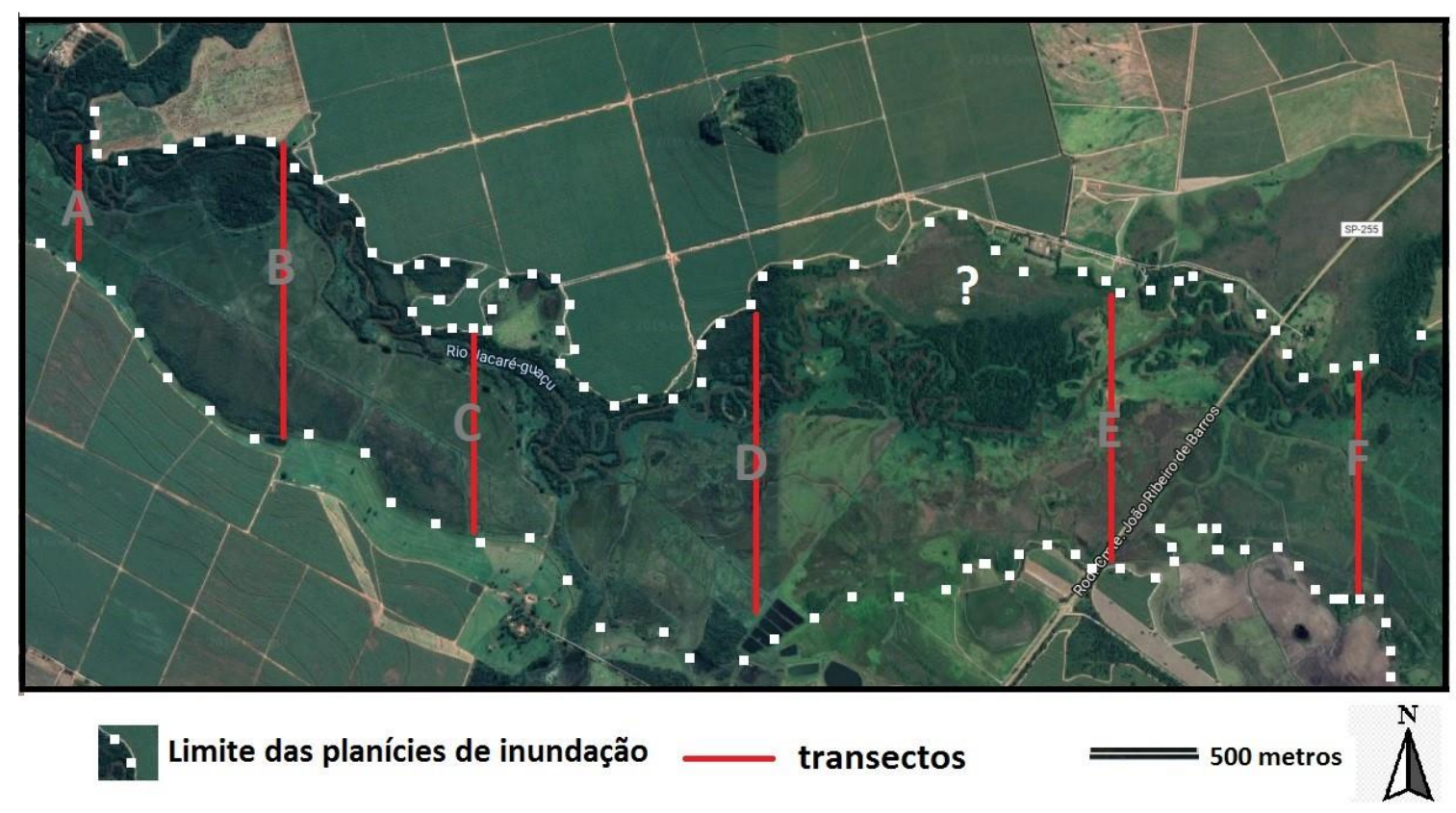

Figura 5 - Transectos e limites da planície de inundação do rio Jacaré-Guaçu. 
Revista Brasileira de Geografia Física, Vol. 13, n. 05 (2020) 1970-1993.

Tabela 2 - Largura da planícies de inundação do rio Jacaré-Guaçu, ao longo dos transectos N-S A a F, cuja localização é indicada na figura 5.

\begin{tabular}{|c|c|c|c|}
\hline Transecto & $\begin{array}{c}\text { Largura } \\
\text { total }(\mathrm{m})\end{array}$ & $\begin{array}{c}\text { Largura na } \\
\text { margem esquerda, } \\
\text { sul }(\mathrm{m})\end{array}$ & $\begin{array}{c}\text { Largura na } \\
\text { margem direita, } \\
\text { norte }(\mathrm{m})\end{array}$ \\
\hline A & 500 & 470 & 30 \\
\hline B & 1090 & 1030 & 60 \\
\hline C & 750 & 700 & 50 \\
\hline D & 1300 & 950 & 350 \\
\hline E & 1200 & 900 & 300 \\
\hline F & 1000 & 800 & 200 \\
\hline
\end{tabular}

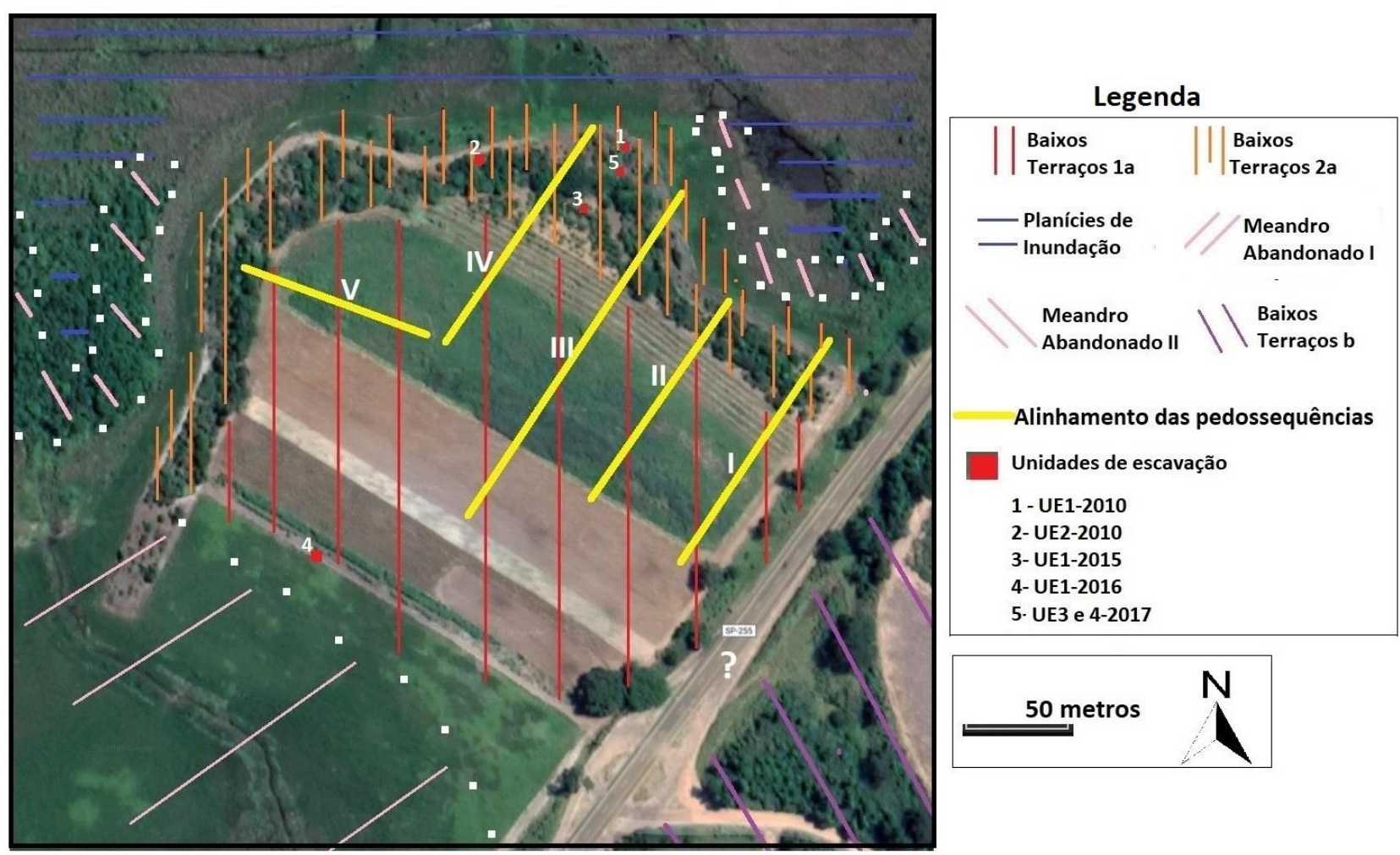

Figura 6. Feições morfológicos do segmento da área de estudo em que se concentraram as intervenções verticais do presente trabalho. Ponto de interrogação representa área onde terreno se caracteriza por cortes artificiais ligados a abertura de estrada, e onde, assim, não foi possível determinar a qual dos subconjuntos de baixos terraços estaria associada. 


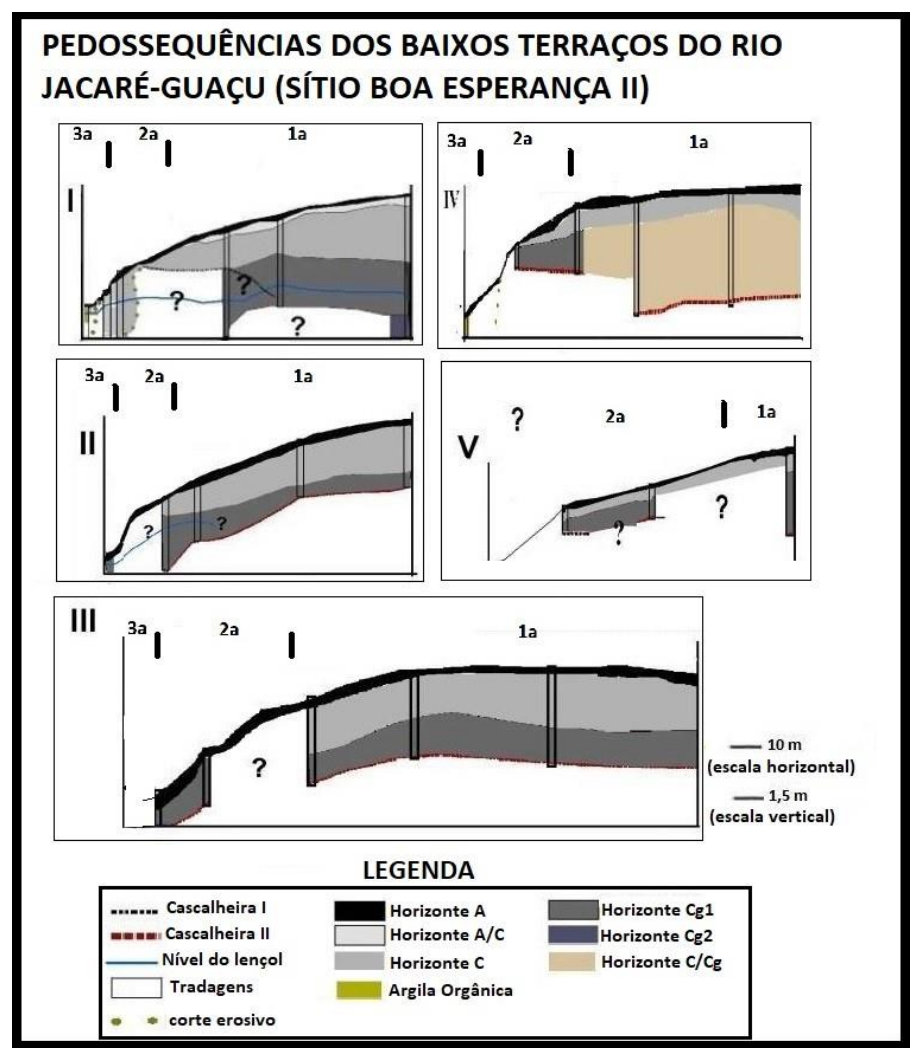

Figura 7. Caracterização da variação vertical e horizontal dos horizontes de solo locais, com transectos I, II, III, IV e V distribuídos na área conforme ilustrado na figura 6.

arenosa. O Horizonte A em geral mostra-se disposto diretamente sobre o Horizonte $\mathrm{C}$, sem Horizonte B no conjunto das tradagens realizadas. Níveis de mosqueamento (cores próximas a 2,5 YR 5/8 na Carta Munsell) mostram-se dispersos nos perfis, em especial no Horizonte C (Cheliz, 2016).

Registram-se, ainda, dois tipos diversos de cascalheiras ao longo das tradagens. $\mathrm{O}$ primeiro deles - denominado tipo I - é composto por camadas de seixos pouco espessas (de 1 a 4 $\mathrm{cm}$ ), e não capazes de impedir a continuidade da tradagem. O segundo - tipo II - impossibilita a continuidade das tradagens, usualmente marcando a ponta do trado com óxi-hidróxidos de ferro. As cascalheiras do tipo II lembram as cascalheiras basais vinculadas a seixos de arenitos ferruginizados das unidades de escavação dos Baixos Terraços, como consta nos dados da Unidade de Escavação 1-2010, 1-2015, e 2, 3 e 42017.

\section{Atributos essenciais das unidades de escavação $e$ idades LOE ${ }^{14} \mathrm{C}$}

A figura 6 apresenta a distribuição dos conjuntos das oito unidades de escavação efetuadas ao longo dos Baixos Terraços a. Seus atributos sumários, baseados em seções verticais, encontram-se registrados nas figuras 8 e 9 , e nas tabelas 3 e 4.

Parte dos atributos dos perfis verticais das unidades de escavação citadas é compartilhada nas UE01-2010, UE01-2015, UE03-2017 e UE042017. Inclui-se a presença de uma cascalheira basal com granulometria média entre 8 e $20 \mathrm{~cm}$ (chegando ao máximo de $40 \mathrm{~cm}$ na UE01-2010, figura 9), clasto-suportada, com matriz de areia grossa acinzentada, clastos rudáceos bem arredondados de formato predominante próximo do esférico (com maiores apresentando também formato oblato) e composições majoritárias de arenito (litologia dominante, com ferruginização no interior) e silexito, com presença menor de quartzito, quartzo e mesmo granito. Ferricretes, tanto na forma de clastos rudáceos, quanto na forma de cimento revestindo e unindo clastos ferruginizados, também foram registrados na UE1-2010. A profundidade nas quais a cascalheira se encontra varia entre $40 \mathrm{~cm}$ (UE1-2010) e 110 cm (UE1-2015).

As unidades de escavação apresentam também coberturas areno-argilosas ou argiloarenosas dispostas sobre a cascalheira, caracterizadas por intensa gleização, em suas porções basais, e horizontes superficiais (entre 10 e $20 \mathrm{~cm}$ ) marcados por maior concentração de 
Revista Brasileira de Geografia Física, Vol. 13, n. 05 (2020) 1970-1993.

raízes.

Na UE3-2017, a concentração de inferior à da fração arenosa da matriz da cascalheira subjacente.

feldspatos na fração arenosa das coberturas arenoargilosas rentes a cascalheiras é mais de dez vezes

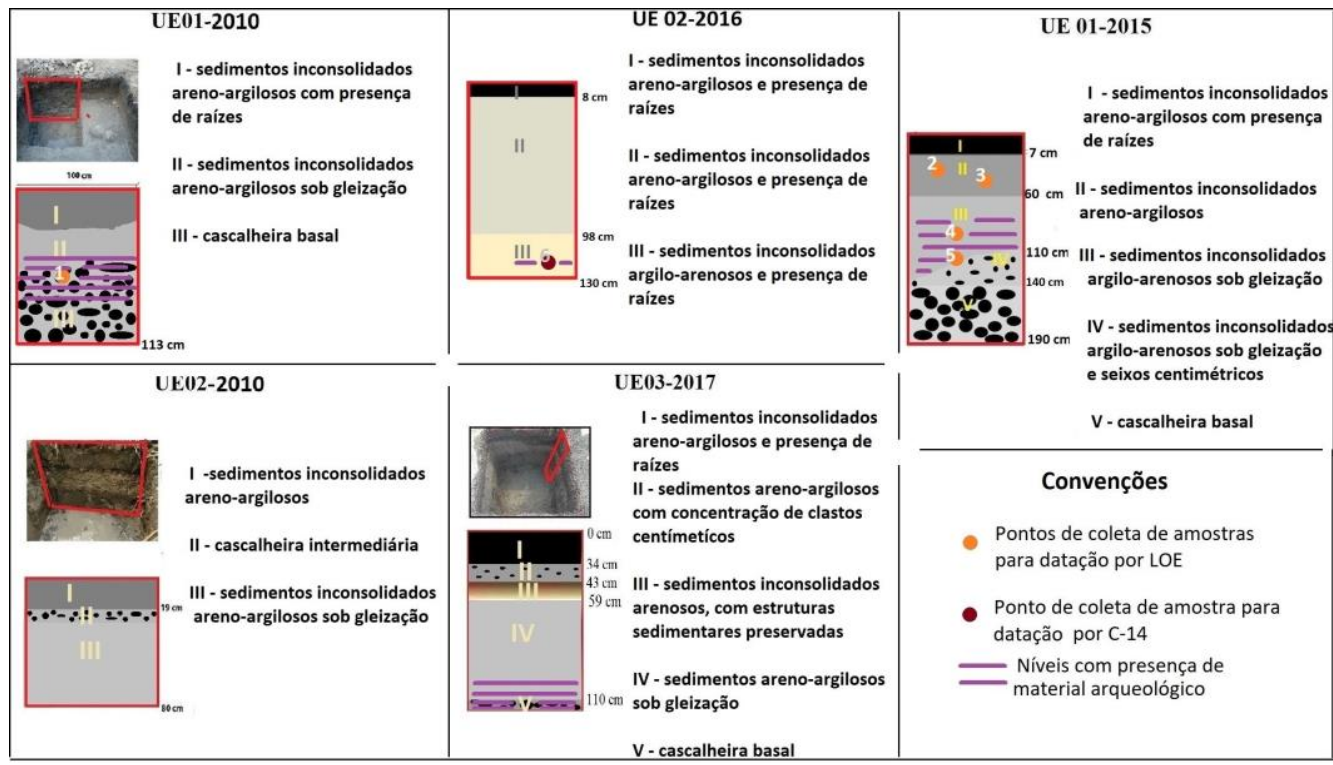

Figura 8. Aspectos sumários dos perfis das unidades de escavação dos baixos terraços do rio Jacaré-Guaçu, e localização dos pontos de coletas de amostras para datações. Distribuição das unidades de escavação se dá como representado na figura 6. Composição feita a partir de perfis e fotos do primeiro autor e de Santos (2011).
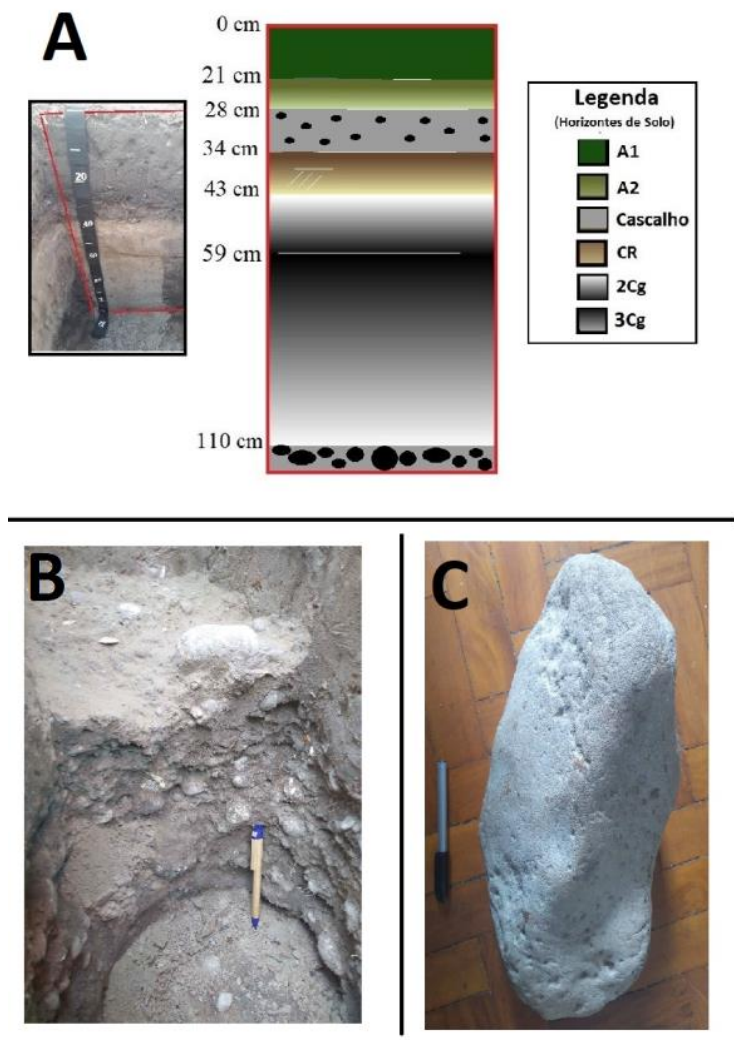

Figura 9. Detalhes das unidades de escavação efetuadas: (A) caracterização macromorfológica da UE3-2017; (B) fotografia obtida em 2019 de corte vertical efetuado em meio a cascalheira basal, a partir do seu contato com os sedimentos areno-argilosos sobrejacentes, onde se evidenciam o caráter clasto-suportado da cascalheira, a intensa gleização do solo superimposto e o caráter sub-horizonal do contato da cascalheira com suas coberturas; (C) clasto que apresenta as maiores dimensões dentre os registrados no conjunto das unidades de escavação; notar formato oblato, comum nos clastos maiores, e grau de arredondamento similar 
Revista Brasileira de Geografia Física, Vol. 13, n. 05 (2020) 1970-1993.

ao dos clastos esféricos.

Tabela 3 - Macromorfologia da Unidade de Escavação 03-2017

\begin{tabular}{|c|c|c|c|c|c|c|}
\hline \multirow[t]{2}{*}{ Horizonte } & Profundidade & Cor & Estrutura & Transição & \multirow{2}{*}{$\begin{array}{c}\text { Textura } \\
\text { Embrapa } \\
(2006)\end{array}$} & \multirow[t]{2}{*}{$\begin{array}{c}\text { Outras } \\
\text { observações }\end{array}$} \\
\hline & $\mathrm{cm}$ & Munsell & \multicolumn{2}{|c|}{ Santos et al. (2005) } & & \\
\hline A1 & $0-21$ & $\begin{array}{c}\text { 10YR 3/2 } \\
\text { (seco) e } \\
10 \mathrm{YR} 2 / 1 \\
\text { (úmido) }\end{array}$ & $\begin{array}{c}\text { Blocos } \\
\text { subangular } \\
\text { es médios, } \\
\text { grandes e } \\
\text { moderados }\end{array}$ & Clara plana & $\begin{array}{c}\text { Areno- } \\
\text { argilosa, } \\
\text { ligeiramente } \\
\text { plástica, } \\
\text { ligeiramente } \\
\text { pegajosa }\end{array}$ & $\begin{array}{l}\text { Ligeiramente } \\
\text { duro, ligeiramente } \\
\text { friável }\end{array}$ \\
\hline A2 & $21-28$ & $\begin{array}{l}10 \text { YR 3/1 } \\
\text { (seco) e } \\
10 \text { YR 2/1 } \\
\text { (úmido) }\end{array}$ & $\begin{array}{l}\text { Blocos } \\
\text { médios } \\
\text { grandes }\end{array}$ & $\begin{array}{l}\text { Plana } \\
\text { abrupta }\end{array}$ & $\begin{array}{l}\text { Areno- } \\
\text { argilosa, } \\
\text { ligeiramente } \\
\text { plástica, } \\
\text { ligeiramente } \\
\text { pegajosa }\end{array}$ & $\begin{array}{l}\text { Ligeiramente } \\
\text { duro }\end{array}$ \\
\hline Cascalho & $28-34$ & - & - & $\begin{array}{c}\text { Abrupta/pla } \\
\text { na }\end{array}$ & - & $\begin{array}{c}\text { Cascalheira } \\
\text { clasto-suportada, } \\
\text { clastos de } 0,5 \text { a } 3 \\
\mathrm{~cm} \text {, arredondados } \\
\text { a } \\
\text { subarredondados }\end{array}$ \\
\hline CR & $34-43$ & $\begin{array}{l}\text { 10YR 7/2 } \\
\text { (seco), } \\
\text { 10YR 6/1 } \\
\text { (úmido) }\end{array}$ & Maciço & $\begin{array}{l}\text { Abrupta e } \\
\text { irregular }\end{array}$ & $\begin{array}{c}\text { Arenosa, não } \\
\text { plástica, não } \\
\text { pegajosa }\end{array}$ & $\begin{array}{c}\text { Ligeiramente } \\
\text { dura, muito } \\
\text { friável, estruturas } \\
\text { sedimentares } \\
\text { (estratificações } \\
\text { incipientes), } \\
\text { clastos dispersos } \\
\text { de } 3 \text { a } 5 \mathrm{~mm}\end{array}$ \\
\hline $2 \mathrm{Cg}$ & $43-59$ & $\begin{array}{c}\text { 10YR } 6 / 1, \\
\text { segmentos } \\
\text { mais } \\
\text { arenosos } \\
\text { com } 10 \\
\text { YR } 5 / 8, \\
\text { com } \\
\text { porções } \\
\text { laminares } \\
10 \mathrm{YR} \\
5 / 8,5 / 1 \text { e } \\
7 / 2\end{array}$ & $\begin{array}{l}\text { Maciço e } \\
\text { friável }\end{array}$ & Clara & $\begin{array}{l}\text { Arenosa, não } \\
\text { plástica, não } \\
\text { pegajosa }\end{array}$ & $\begin{array}{l}\text { Seixos dispersos } \\
\text { de até } 5 \mathrm{~mm} \text {, } \\
\text { resquícios de } \\
\text { estruturas } \\
\text { sedimentares, } \\
\text { duro }\end{array}$ \\
\hline $3 \mathrm{Cg}$ & $59-110$ & $\begin{array}{l}\text { G2 7/5 PB } \\
\text { (úmido) } \\
\text { com } \\
\text { mosquead } \\
\text { os } 7,5 \mathrm{YR} \\
5 / 8 \text { e } 7 / 8\end{array}$ & $\begin{array}{l}\text { Maciço e } \\
\text { friável }\end{array}$ & $\begin{array}{l}\text { Abrupta e } \\
\text { irregular }\end{array}$ & $\begin{array}{l}\text { Argilo- } \\
\text { arenosa, } \\
\text { plástica e } \\
\text { pegajosa }\end{array}$ & $\begin{array}{l}\text { Nódulos de ferro } \\
\text { na porção } \\
\text { superior, friável, } \\
\text { seixos dispersos } \\
\text { de até } 2 \mathrm{~cm}\end{array}$ \\
\hline
\end{tabular}

Fonte: elaboração própria a partir dos dados de campo. 
Tabela 4 - Datações absolutas disponíveis, com pontos de retirada retratados na figura 8 (adaptado de Santos 2011, Cheliz et al. 2018 e Santos e Cheliz, 2017 e 2019).

\begin{tabular}{|c|c|c|c|c|c|}
\hline $\begin{array}{l}\text { Número da } \\
\text { datação e de } \\
\text { laboratório } \\
\text { (entre } \\
\text { parêntesis) }\end{array}$ & Método & $\begin{array}{l}\text { Idade (milhares } \\
\text { de anos) }\end{array}$ & $\begin{array}{l}\text { Unidade de } \\
\text { Escavação e } \\
\text { profundidade }\end{array}$ & Laboratório & Observações \\
\hline 1 & LOE & $14,5+-3,0$ & $\begin{array}{c}\text { UE1-2010, } 55 \\
\mathrm{~cm}\end{array}$ & FATEC & $\begin{array}{c}\text { Cascalheira } \\
\text { basal }\end{array}$ \\
\hline 2 (UW3525) & LOE & $1,42 \pm 0,18$ & $\begin{array}{c}\text { UE1-2015, } 30 \\
\mathrm{~cm}\end{array}$ & $\begin{array}{l}\text { University of } \\
\text { Washington }\end{array}$ & $\begin{array}{c}\text { Cobertura } \\
\text { areno-argilosa }\end{array}$ \\
\hline 3 (UW3524) & LOE & $2,60 \pm 0,26$ & $\begin{array}{c}\text { UE1-2015, } 54 \\
\mathrm{~cm}\end{array}$ & $\begin{array}{l}\text { University of } \\
\text { Washington }\end{array}$ & $\begin{array}{c}\text { Cobertura } \\
\text { areno-argilosa }\end{array}$ \\
\hline 4 (UW3523) & LOE & $4,09 \pm 0,34$ & $\begin{array}{c}\text { UE1-2015, } 92 \\
\mathrm{~cm}\end{array}$ & $\begin{array}{l}\text { University of } \\
\text { Washington }\end{array}$ & $\begin{array}{c}\text { Cobertura } \\
\text { areno-argilosa }\end{array}$ \\
\hline 5 (UW3522) & LOE & $10,9 \pm 1,2$ & $\begin{array}{c}\text { UE1-2015, } 113 \\
\mathrm{~cm}\end{array}$ & $\begin{array}{l}\text { University of } \\
\text { Washington }\end{array}$ & $\begin{array}{c}\text { Cobertura } \\
\text { areno- } \\
\text { argilosa, rente } \\
\text { a cascalheira }\end{array}$ \\
\hline 6 & C-14 & $\begin{array}{c}\text { 7,94+-0,30 AP } \\
\text { (idade } \\
\text { convencional) } \\
8,850-8,835, \\
8,775-8,600 \text { AP } \\
\text { cal }\end{array}$ & $\begin{array}{c}\text { UE2-2016, } 120 \\
\mathrm{~cm}\end{array}$ & Beta Analytic & $\begin{array}{c}\text { Cobertura } \\
\text { argiloso- } \\
\text { arenosa }\end{array}$ \\
\hline
\end{tabular}

Foram efetuadas cinco datações por LOE e uma por ${ }^{14} \mathrm{C}$ a partir, respectivamente, de amostras de sedimentos e carvões, recolhidas em meio às UE1-2010, UE1-2015 e UE1-2016 (tabela 4 e figura 9).

As idades obtidas inserem-se entre o Pleistoceno Tardio e o Holoceno Tardio. A distribuição das idades mostra-se concordante com a estratigrafia local, sem inversões aparentes.

\section{Granulometria}

Dentre as unidades de escavação efetuadas no sítio BES II, foram obtidos para a UE3-2017 dados de granulometria mais detalhados (figura 10). Nota-se predomínio da fração areia (proporção em massa de 64 a 88\%) ao longo do perfil analisado. Existem significativas variações entre predomínio de areia grossa (cuja proporção vai de 32 a $73 \%$ ) e de areia fina (14 a $39 \%)$ ao longo do perfil vertical. De maneira semelhante existem expressivas variações verticais no que se refere aos porcentuais de argila (10 a $21 \%$ ) e silte (até $11 \%$ ).

Nota-se tendência de crescimento da classe areia grossa, dos segmentos mais profundos dos perfis aos intermediários (entre $3 \mathrm{Cg}$ e a cascalheira intermediária - 110 a $28 \mathrm{~cm}$ ).

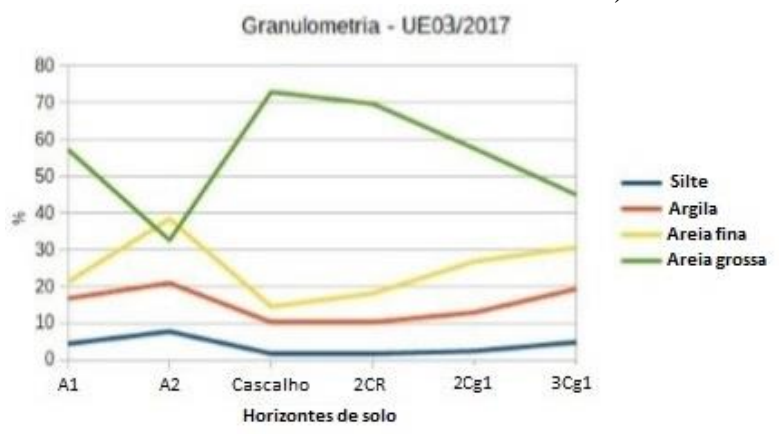

Figura 10. Variações granulométricas ao longo do perfil da UE3-2017. 


\section{Composição química}

Dentre as unidades de escavação, foram obtidos dados referentes a caracterização química para a UE03-2017. Os resultados obtidos encontram-se sumariados nas figura 11 e 12.

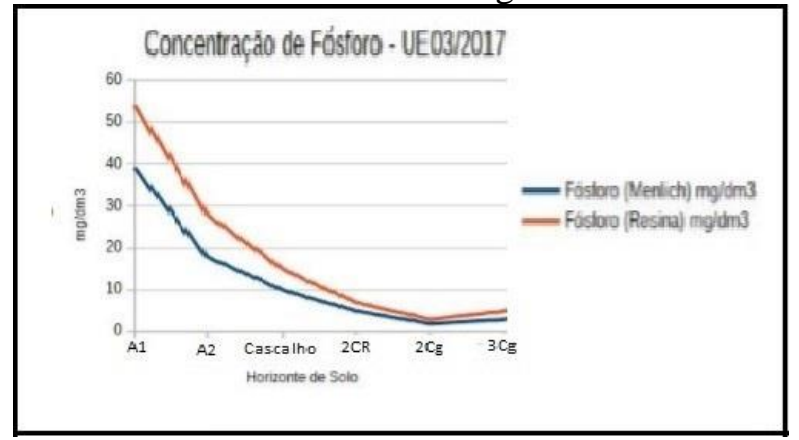

Figura 11. Variação da presença de fósforo no perfil da UE3-2017.

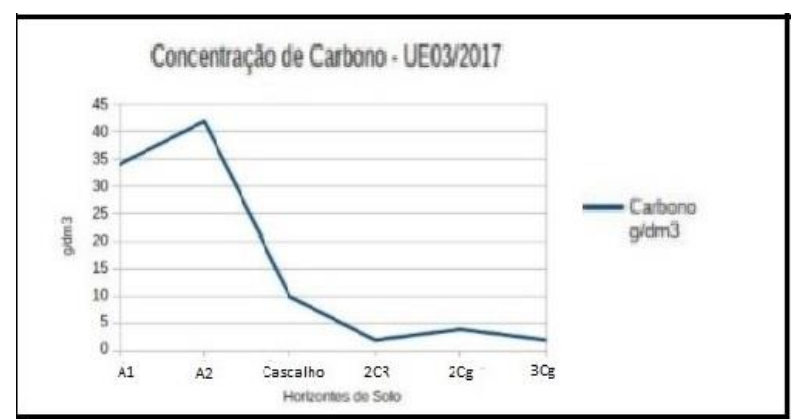

Figura 12. Variação da presença de carbono no perfil da UE3-2017.

Ressaltam-se nos dados obtidos pela análise química as assimetrias e descontinuidades na distribuição vertical de fósforo e carbono. Particularmente, destaca-se que a tendência de decréscimo na concentração de fósforo conforme se afasta do topo do perfil é descontinuada nos horizontes mais profundos. Na UE3-2017, o horizonte $3 \mathrm{Cg}$ apresenta concentrações de fósforo entre 50\% maiores (Menlich) e o dobro (resina) do que o horizonte sobrejacente, $2 \mathrm{Cg}$.

Esse padrão de distribuição permite sugerir a existência em meio ao perfil de dois conjuntos distintos de solos: um mais antigo, referente ao horizonte 3Cg (UE3-2017); e outro mais recente, referente aos horizontes sobrejacentes.

\section{Caracterização petrográfica e micromorfológica das amostras indeformadas}

A fração grossa mostra-se predominante no conjunto das lâminas da UE3-2017, perfazendo no mínimo $70 \%$ do total do fundo matricial (figuras 13, 14 e 15). A fração fina corresponde, em média, a $10 \%$ do fundo matricial. Nota-se, ainda, uma presença mais expressiva da fração fina (20\%) em lâminas de segmentos mais profundos (horizonte $3 \mathrm{Cg}$ ) da unidade de escavação do que nas dos segmentos intermediários.

O padrão de distribuição predominante mostra-se quitônico na totalidade das lâminas (figura 14). A microestrutura é predominantemente marcada pela presença de grãos com películas: uma primeira, opaca e de coloração preta, envolve diretamente os grãos da fração grossa, enquanto a segunda, translúcida, pode tanto envolver a primeira fração fina quanto preencher parte dos poros remanescentes.
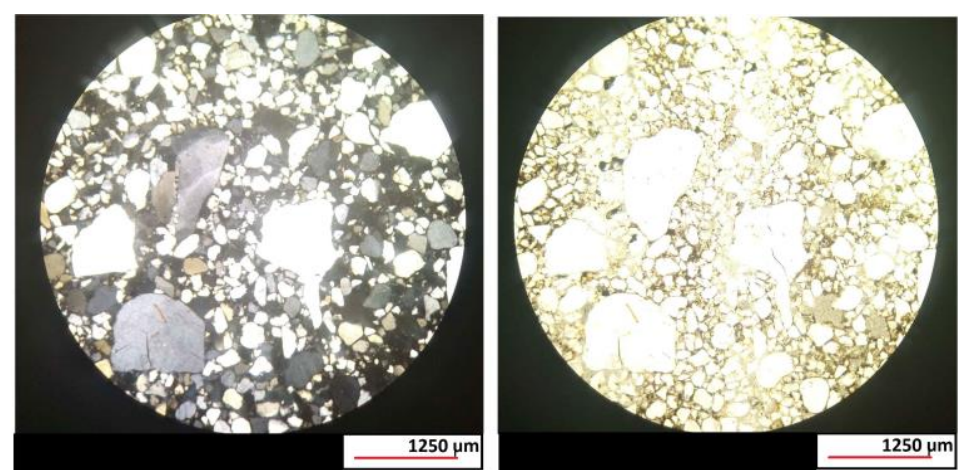

Figura 13. Composição com fotomicrografias ilustrativas das proporções entre fração grossa e fração fina e da bimodalidade granulométrica da fração grossa, cuja composição é dominada por quartzo. Polarizadores cruzados (esquerda) e paralelos (direita). Na moda mais grossa, notar grão anguloso com extinção semicomposta (metade superior das imagens, à esquerda) e grão subanguloso com proeminência alongada (meiodireita das imagens). Amostra $2 \mathrm{Cg}$. 

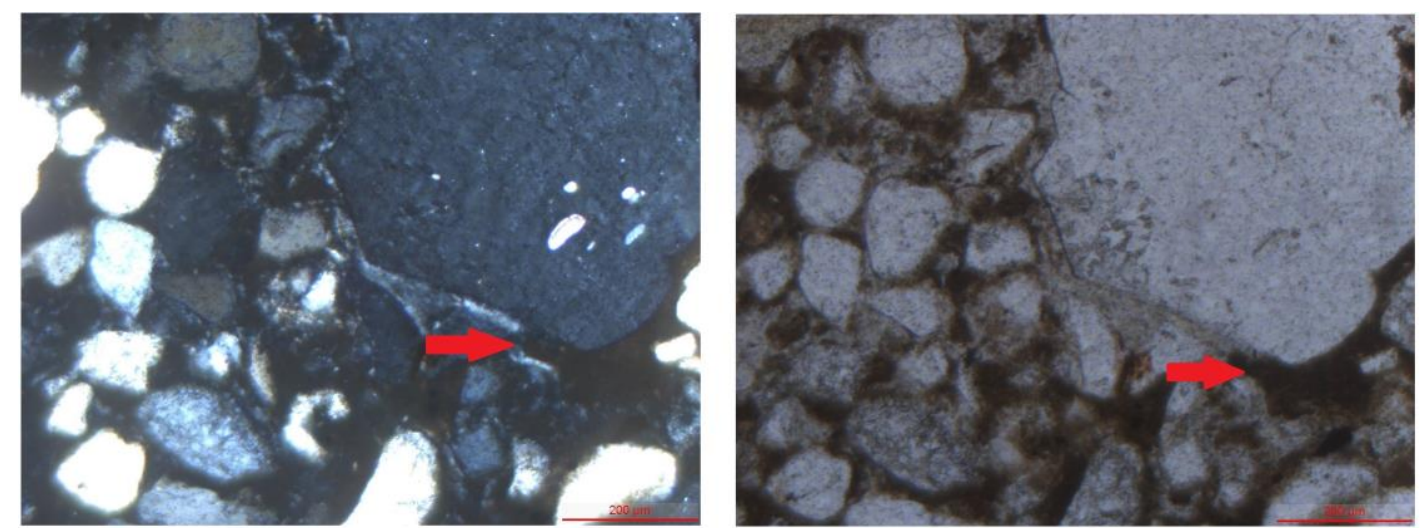

Figura 14. Detalhe de trama da fração fina, comum a diversas das lâminas estudadas, caracterizada por películas anisópacas em torno dos grãos. Fotomicrografias a polarizadores cruzados (esquerda) e paralelos (direita). Lâmina 3Cgb.
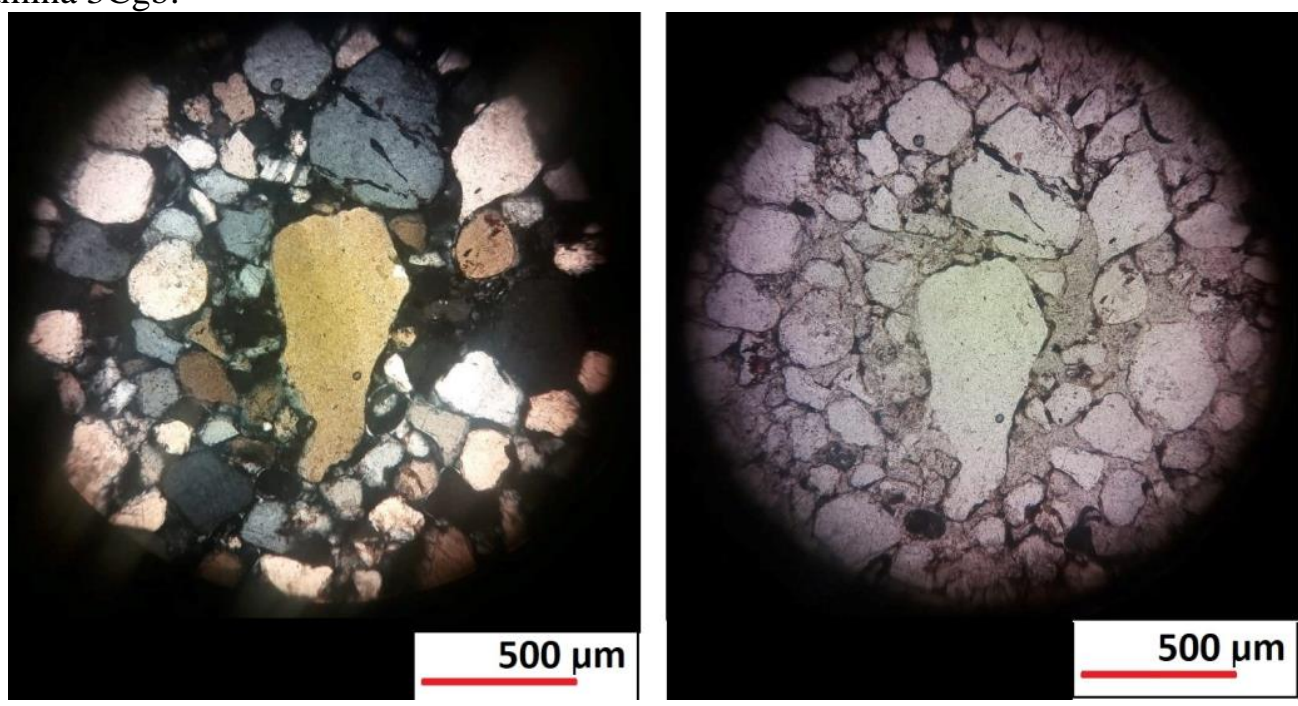

Figura 15. Fração grossa quartzosa, na qual se destaca, ao centro, grão maior caracterizado por contorno em ângulos obtusos e reentrância próxima de 90 graus. Fotomicrografias a polarizadores cruzados (esquerda) e paralelos (direita). Amostra 3CGa.

Em uma parcela das lâminas (como na correlata ao horizonte $3 \mathrm{Cg}$ ), nota-se que parte das películas é anisópaca, mostrando-se maiores nas porções inferiores dos grãos que envolvem, o que caracteriza arranjo pendular (figura 14).

A fração grossa apresenta claro padrão de distribuição granulométrica bimodal (figura 14), na qual um número reduzido de grãos, na faixa de 0,5 a $4 \mathrm{~mm}$, flutua em meio a grãos de areia mais fina $(0,125$ a $0,25 \mathrm{~mm})$, que são dominantes. $O$ grau de arredondamento dos grãos mostra-se heterogêneo, e aparentemente, varia com a granulometria. Assim, os grãos da moda de granulometria mais grossa, incluindo raros grânulos, mostram-se usualmente mal arredondados, enquanto os grãos da moda principal, mais fina, são, em contraste, predominantemente subarredondados a bem arredondados.

A fração grossa apresenta o predomínio de quartzo como componente mineralógico, tanto na sua moda granulométrica mais grossa, quanto na moda principal, mais fina. Este mineral perfaz mais de $85 \%$ em média dos grãos identificados no conjunto das lâminas descritas, e mais de $95 \%$ quando se considera apenas a moda mais grossa (figura 14). Dentre os minerais com presença subordinada, notam-se feldspatos (plagioclásios) dispersos e isolados, mais comuns na moda mais fina. Incluem-se, também, na mesma moda, minerais pesados. Registrou-se, ainda, um possível fitólito na lâmina 3Cg da UE3-2017.

Nas lâminas obtidas a partir de amostras indeformadas retiradas em horizontes arqueológicos, e próximos a locais onde foram registrados artefatos (como nas lâminas dos horizonte $3 \mathrm{Cg}$ e $2 \mathrm{Cg}$ ), a angulosidade de alguns dos grãos maiores de quartzo (acima de 0,5 mm), é marcada por proeminências alongadas, contornos em ângulos obtusos e reentrâncias (por vezes próximas do 90 graus - figura 14 e 15). Vários desses grãos mostram extinção semicomposta ("grãos semi-compostos" sensu Krynine, 1950 e Folk, 1974), isto é, sutil 
compartimentação interna em um mesmo cristal, com pequena diferença de luminosidade a polarizadores cruzados, e de posição de extinção óptica, entre os compartimentos.

\section{Integração dos dados e discussão}

Propõe-se que as transformações geomorfológicas, ambientais e climáticas associadas à geomorfogênese dos Baixos Terraços possam ser abordadas em três fases (I, II e III) de formação da paisagem (figura 16).

A fase I envolveria a deposição dos cascalhos basais, caracterizados nas unidades de escavação 1-2010, 1-2015 e 3-2017, cuja distribuição englobaria maior parte das extensões abrangidas pelas pedossequências I, II, III, IV e V. Esta ampla correlação baseia-se na associação entre duas evidências: a cascalheira do tipo II alcançada pelas tradagens das pedossequências coincide com o topo da cascalheira basal nas unidades de escavação; os clastos de ambas as cascalheiras marcam a ponta do trado com óxihidróxido de ferro. Sugere-se, assim, extrapolar a distribuição do topo das cascalheiras basais em subsuperfície para a área em que foi detectada a cascalheira do tipo II nas tradagens usadas para delimitar as pedossequências,

Os atributos de trama e textura dos clastos da cascalheira basal (i.e., dimensão média ao menos quatro vezes maior que seixos do atual rio Jacaré-Guaçu, bom arredondamento, semelhanças texturais com seixos fluviais atuais e presença de imbricação) incluem-se entre os apontados por Goudie (2013) como característicos de produtos deposicionais de canais torrenciais efêmeros. Esse tipo de processo deposicional é frequente em climas menos úmidos que o atualmente vigente na área de estudo, quando expostos a precipitações sazonais, como se tem hoje no norte da Argentina e no interior da Região Nordeste do Brasil - em consonância com a interpretação anteriormente apresentada por Cheliz (2011, 2012, 2013a e b, 2015 e 2016) e Santos e Cheliz (2017 e 2019). Sem a presença de associações vegetais densas, dotadas de copas amplas o bastante para amenizar o impacto das gotas de chuva nos solos, áreas com essas condições climáticas favorecem chuvas mais pontuais, com formação de enxurradas de curta duração (até algumas horas), cuja capacidade e competência de transporte é maior do que a dos atuais rios perenes que prevalecem na área de estudo, como o próprio rio Jacaré-Guaçu. A concentração de feldspato em meio à matriz arenosa da cascalheira basal, muito maior que a da fração arenosa dos depósitos areno-argilosos sobrejacentes, parece reforçar a hipótese de clima mais seco durante ou imediatamente antes da deposição dessa cascalheira. Este raciocínio baseia-se no fato de, em condições quentes e úmidas como as atuais, os feldspatos se desagregarem com relativa facilidade por intemperismo, enquanto climas secos favorecem sua preservação (Castro e Cooper, 2019).

Ab`Saber (1998) aponta como comum, em vastas extensões do Sul-Sudeste do Brasil, a formação de depósitos de canais torrenciais efêmeros entre o Pleistoceno Tardio e a transição Pleistoceno-Holoceno, intervalo no qual se insere a idade por datação LOE na cascalheira basal da UE1-2010. O mesmo autor considera que a formação de tais depósitos teria ligação com a passagem de um longo intervalo em que teriam prevalecido condições mais secas que as atuais, para outro, marcado por incrementos na pluviosidade. Esta interpretação mostra-se em parte coerente também com a reconstituição paleoclimática de Cruz et al. (2005, 2006), feita a partir de registros de isótopos de oxigênio em espeleotemas do Sul-Sudeste do Brasil, que caracteriza uma queda bem marcada de umidade, entre cerca de 15 e 12 mil anos atrás, seguida de um período em que dominou tendência para aumento de umidade. $\mathrm{O}$ intervalo de transição entre estes dois padrões climáticos teria favorecido que chuvas mais volumosas carreassem o material intemperizado durante a prolongada fase mais seca anterior, e que correntes torrenciais efêmeras se formassem no rio. Aviles et al. (2019) em estudo palinológico na região de Campinas (SP), de fato caracterizam o Pleistoceno Tardio - entre 25 e 13 mil anos atrás como vinculado a condições climáticas dominantemente mais secas que as atuais.

A fase II de evolução da paisagem envolve ascensão do nível de base de até $7 \mathrm{~m}$, evidenciada pelo desnível vertical entre o topo da cascalheira da UE3-2017 e UE1-2010 e o meandro abandonado do tipo I nos Baixos Terraços a. Esta ascensão incluiria a idade de 10900+-1160 anos atrás (datação das coberturas arenosas sobre a cascalheira basal da UE1-2015 nos Baixos Terraços 2a) e se estenderia ao menos até 8800 anos antes do presente (idade ${ }^{14} \mathrm{C}$ calibrada obtida nas coberturas argilo-arenosas da UE1-2016, adjacentes ao meandro abandonado do tipo I nos Baixos Terraços 1a), podendo ter 


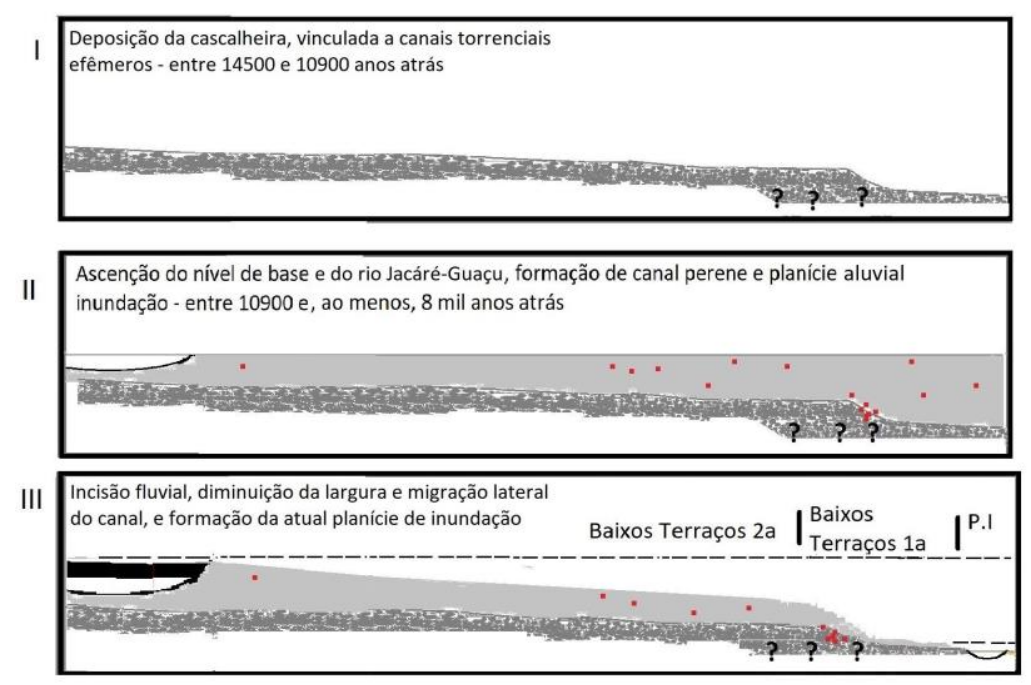

\section{Legenda}

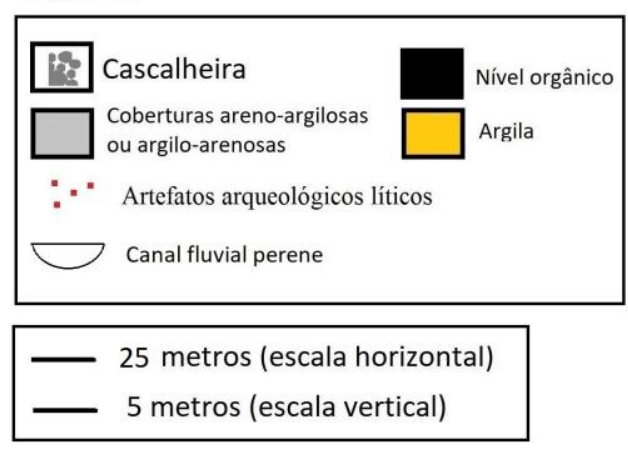

Figura 16 - Fases propostas de transformações geomorfológicas dos Baixos Terraços do rio Jacaré-Guaçu (sítio arqueológico BES II).

prosseguido até o Holoceno Médio (idade LOE das coberturas argilo-arenosas intermediárias da UE1-2015). A idade de fecho desta fase permanece pendente de ser melhor estabelecida por meio de futura obtenção de datação absoluta nos depósitos arenosos mais superficiais do paleocanal de meandro abandonado do tipo I.

A ascensão do nível de base da fase II não teria necessariamente ocorrido de modo linear ou uniforme, e teria sido acompanhada de significativas alterações nas condições hidrológicas, climáticas, de sedimentação e pedogênese vigentes, em relação à fase I. As alterações hidrológicas incluiriam a passagem de canais torrenciais efêmeros, responsáveis pela deposição das cascalheiras basais, para canais perenes, representados pelo meandro abandonado do tipo I no topo dos Baixos Terraços; as alterações na sedimentação incluiriam $o$ estabelecimento de ampla planície aluvial, que teria depositado ao menos uma parcela dos sedimentos areno-argilosos e argilo-arenosos sobre cascalheiras basais observadas nos perfis das UE1-2015, UE3-2017 e UE1-2016; e as alterações pedogenéticas estariam ligadas a elevação do lençol freático e possível aumento da umidade, evidenciada pela gleização desses depósitos sedimentares e pela presença de um horizonte plíntíco nos segmentos basais da UE12015; no entanto, o sistema fluvial ainda teria características distintas do atual rio Jacaré-Guaçu, isto é, maior largura do canal. Simultaneamente, a ascensão do nível de base em até $7 \mathrm{~m}$ da fase II implicaria a ascensão do próprio rio Jacaré-Guaçu, na medida que ao menos uma parcela dos sedimentos das coberturas areno-argilosas é interpretada como de origem fluvial.

As interpretações paleoambientais apresentadas para a fase II mostram-se concordantes com a caracterização paleoambiental para o interior do Estado de São Paulo efetuada a partir do estudo de baixos terraços do rio MogiGuaçu por Celarino (2011) e Sousa (2010), que apontam crescimento de umidade no Holoceno Inicial após 10 mil anos atrás. A interpretação da modificação do nível de base local e de posição vertical do rio Jacaré-Guaçu na fase II, é, porém, distinta da sugerida em estudos prévios de geomorfologia fluvial na Bacia Sedimentar do Paraná (Penteado, 1976; Celarino, 2011 e 2015; Dias, 2015 Oliveira et al. 2019; Lupinacci e Souza, 2019). Esses estudos caracterizam o predomínio de rebaixamentos e incisões dos canais principais dos sistemas fluviais por eles estudados, no Holoceno, enquanto o presente estudo indica a ascensão em até $7 \mathrm{~m}$ do nível de base local e da calha do rio Jacaré-Guaçu ao longo do Holoceno Inicial. Dessa maneira, os processos de gênese da paisagem local envolveriam, de acordo com a interpretação aqui adotada, o empilhamento dos terraços fluviais no Holoceno, enquanto os trabalhos citados sugerem o predomínio de incisão fluvial no mesmo intervalo de tempo. A fase II corresponde, assim, à sedimentação mais expressiva ligada à formação dos baixos terraços fluviais locais, com idade significativamente mais recente do que a dos baixos terraços fluviais também associados a registros arqueológicos estudados por Cunha et al. (2019).

A associação dos dados de tamanho de grão, grau de seleção granulometria, 
Revista Brasileira de Geografia Física, Vol. 13, n. 05 (2020) 1970-1993.

arredondamento e trama das amostras indeformadas sugere ainda que os processos deposicionais envolvidos na fase II foram predominantemente trativos. Ao menos parte das variações granulométricas observadas ao longo dos cortes verticais indicariam mudanças de fácies de um mesmo sistema deposicional e/ou da energia hidrodinâmica que elas materializam e/ou de distribuição espacial destas fácies - como, por exemplo, vinculadas a aproximação ou distanciamento do canal fluvial principal por meio de sua migração lateral ao longo do tempo. A favor desta linha interpretativa, ressalta-se também o decréscimo gradual da base para o topo da granulometria e da abundância dos seixos de cascalho dispersos em meio às coberturas arenosas ao longo de toda a extensão vertical dos horizontes $2 \mathrm{Cg}$ e 3Cg nos perfis da UE3-2017, mas com manutenção dos seus elevados graus de arredondamento e esfericidade. A distribuição granulométrica bimodal dos grãos de quartzo presente ao longo do conjunto das amostras indeformadas analisadas poderia ser, ao menos em parte, uma herança de algumas das unidades rochosas (Formações Botucatu e Piramboia) aflorantes a montante no rio Jacaré-Guaçu (Almeida, 1964), como se pode depreender da caracterização sedimentológica dessas unidades no Estado de São Paulo (Giannini et al., 2004, Caetano-Chang \& Wu, 2005, e Gesicki 2007). Por outro lado, a bimodalidade acentuada, de acordo com mesmos autores, é mais típica das fácies de interdunas da Formação Piramboia, e, de fato, as descrições petrográficas de Meaulo (2007) e Cheliz (2016) em arenitos do município de Araraquara vinculados à Formação Botucatu não identificaram o padrão bimodal. Desse modo, não se pode descartar a hipótese de que a distribuição bimodal encontrada possa resultar somente dos processos do próprio ciclo sedimentar envolvido na construção dos baixos terraços locais. Futuros trabalhos poderão vir a discutir mais a fundo a possibilidade dos sedimentos destes terraços envolverem misturas de grãos de diferentes fontes ou processos, como sugerido pela coexistência de grãos mais grossos pior arredondados que os mais finos (inversão textural - Caetano-Chang \& Wu, 2005).

A fase III envolveria a migração lateral do eixo do canal fluvial por cerca de $100 \mathrm{~m}$ (diferença entre o meandro abandonado do tipo I no topo dos Baixos Terraços 1a e os meandros abandonados do tipo II presentes nas atuais planícies de inundação que seccionam os Baixos Terraços) e o rebaixamento do nível de base local e incisão do canal do rio Jacaré-Guaçu de ao menos $7 \mathrm{~m}$ (diferença entre as altitudes do topo do meandro abandonado do tipo I associado aos Baixos Terraços 1a e as atuais planícies de inundação). Ao longo do rebaixamento do nível de base, uma parte significativa dos depósitos correlatos às fases II e I teria sido erodida, contribuindo para originar os declives mais íngremes que delimitam os Baixos Terraços 2a, enquanto os segmentos pouco afetados por essa erosão estariam associados aos Baixos Terraços $1 \mathrm{a}$.

Ao fecho da fase III, teria-se o estabelecimento da atual planície de inundação do rio Jacaré-Guaçu, seguida pela migração lateral do eixo principal do canal rumo norte por ao menos $500 \mathrm{~m}$, como evidenciado pela distância entre os meandros abandonados do tipo II das planícies de inundação que seccionam os Baixos Terraços 2a e o atual canal do rio Jacaré-Guaçu.

O conjunto de transformações ocorridas na fase III teria se dado no contexto de alterações nos padrões hidrológicos locais (Cheliz, 2013 e 2016), passando de canais perenes até quatro vezes mais largos (como evidenciado pelos meandros abandonados do tipo I) para canais com larguras e eixos de simetrias similares às do atual rio Jacaré-Guaçu (como evidenciado pela geometria em planta dos meandros abandonados do tipo II que se distribuem na atual planície de inundação). Diminuição de largura de canais, com manutenção do padrão meandrante, tem sido registrada também em outras planícies fluviais do Holoceno não muito distantes, como na Bacia Sedimentar do Pantanal, na Região Centro-Oeste (Merino et al. 2013), o que permite cogitar alterações hidrológicas controladas por fatores climáticos. Dentro deste contexto, a redução das dimensões dos canais meandrantes na área de estudo poderia estar ligada à estabilização da precipitação na Região Sul-Sudeste do Brasil no Holoceno Tardio, mostrando-se tal interpretação coerente com Aviles et al. (2019), que em seu estudo de palinologia aponta que a partir de 4 mil anos atrás as florestas atuais da área de Campinas (SP) já estariam plenamente estabelecidas, o que é atribuído pelos autores ao predomínio, desde então, de padrões climáticos quentes e úmidos semelhantes aos atuais.

O rebaixamento do nível de base e da própria altitude do rio Jacaré-Guaçu na fase III implica processos de escalonamento de terraços similares aos registrados para o Holoceno Médio e Tardio em outros estudos de geomorfologia fluvial na Bacia Sedimentar do Paraná (Celarino, 2011 e 2015; Dias, 2015 Oliveira et al. 2019; Lupinacci e Souza, 2019). Processos de incisão 
vertical dos canais fluviais durante o Holoceno foram também registrados em outras porções do território brasileiro, como na Serra do Espinhaço (Carvalho et al., 2018) e na Bacia Sedimentar do Amazonas (Passos et al., 2020), ainda que com rebaixamentos de nível de base maiores que os registrados na área aqui estudada. Já a variação horizontal do rio Jacaré-Guaçu durante a fase III $(600 \mathrm{~m})$ é mais de quatro vezes maior que a registrada por Celarino (2011) nos últimos $10 \mathrm{mil}$ anos para segmento de planície fluvial próximo ( $<30 \mathrm{~km}$ ), do rio Mogi-Guaçu. Cheliz (2016), com base na análise de assimetrias de relevo e drenagem da área de Araraquara (SP) e seus entornos, sugere a presença de basculamentos neotectônicos na área de estudo, que poderiam ter contribuído para esta acentuada migração para norte do rio Jacaré-Guaçu.

O esquema de transformações geomorfológicas e ambientais proposto não implica, em cada uma de suas fases, modificações rigidamente uniformes e lineares. Sugere-se a possibilidade de pausas e inflexões pontuais em meio às tendências de ascensão e rebaixamento do nível de base das fases II e III, a julgar por diferenças observadas na fração fina das amostras indeformadas e pela distribuição dos horizontes de solo nos perfis verticais. Pode-se cogitar que coberturas superficiais areno-argilosas com pedogênese mais desenvolvida (representadas pelo horizonte $3 \mathrm{Cg}$ da UE3-2017) teriam sido truncadas por processos erosivos que se deram entre as fases II e III de evolução da paisagem, e cobertas em seguida por novos sedimentos, estes expostos a processos de pedogênese sob condições ambientais e climáticas (e.g. drenagem dos solos e umidade) distintas das anteriores Sugere-se, também, que o crescimento de umidade após 10 mil anos atrás poderia ter sido intercalado com intervalos de diminuição da umidade e da precipitação, e em condições mais secas que as atuais. Uma característica a favor desta hipótese são as películas anisópacas pendulares registradas no horizonte $3 \mathrm{Cg}$ da UE32017, que sugerem formação em condições vadosas, portanto num momento em que o lençol freático estava significativamente mais baixo que o atual. A presença de condições mais secas que as atuais ao longo de parte do Holoceno são documentados em outras áreas do Brasil com dados arqueológicos, como na porção central do país (Araujo et al., 2005) e no interior do Paraná (Cheliz et al., 2020); bem como nos dados de espeleotemas de Cruz et al. $(2005,2006)$ e Stríkis et al. (2011). Desta maneira, os solos locais mostrariam-se vinculados a condições poligenéticas de pedogênese.

De maneira similar, as assimetrias químicas de fósforo e carbono registradas nos mesmos segmentos do perfil vertical da UE3-2017 (horizontes profundos e intermediários) constituiriam evidências de discordâncias: solos mais antigos (originados a partir da alteração dos sedimentos da fase I e II, ligado ao horizonte $3 \mathrm{Cg}$ e da UE3-2017) teriam permanecido expostos na forma de paleossuperfícies estáveis por tempo o suficiente para a pedogênese, para em seguida serem cobertos por novo aporte sedimentar.

A investigação mais detalhada da fração fina das seções delgadas obtidas a partir das amostras indeformadas e a obtenção de novas datações em meio aos cortes verticais poderão vir a aprofundar discussões sobre tais hipóteses.

Ressalta-se também a possibilidade de os grãos de quartzo com reentrâncias bruscas, parte deles com extinção semi-composta, encontrados nas amostras indeformadas retiradas de horizontes com artefatos arqueológicos, corresponderem a micro-fragmentos de lascamento, ou microartefatos (Dunnel e Stein, 1989; Ricci, 2018). A extinção semi-composta é comum em quartzo ígneo cristalizado sob pressão e com reologia rúptil, formado em condições de resfriamento sob baixa temperatura, como em veios hidrotermais; o quartzo de veio é, porém tipicamente rico em inclusões fluidas (leitoso) (Folk, 1974). Na ausência destas inclusões, não se pode descartar outras origens para a extinção semi-composta, como por exemplo, percussão durante lascamento. Se aceita, esta hipótese seria um argumento a favor de que os artefatos teriam sido originados concomitantemente com os sedimentos onde se encontram, sem remobilização vertical expressiva. Neste caso, a idade de confecção das peças seria a indicada pelas datações de sedimentos e amostras de carvão encontradas próximas a elas; e os artefatos arqueológicos marcariam a presença de paleossuperfícies desenvolvidas no âmbito dos processos de deposição e erosão das coberturas areno-argilosas das fases II e III. O adensamento da caracterização dos possíveis microfragmentos, de acordo com procedimentos da literatura especializada no tema, poderá, assim, trazer subsídios adicionais para o detalhamento das sucessões de flutuações de nível de base que atuaram na geomorfogênese dos Baixos Terraços do rio Jacaré-Guaçu.

A melhor caracterização do material arqueológico poderá contribuir, ainda, para avaliar se a concentração das peças em meio às porções mais superficiais das cascalheiras basais (UE12010), ou nos segmentos das coberturas arenosas 
rentes às cascalheiras (UE1-2015, UE3-2017 e UE4-2017), pode ser também considerada indicativa de paleossuperfície. Desta maneira, a exposição de ampla cascalheira com abundância de clastos de arenito e silexito (materiais similares aos documentados nos artefatos arqueológicos do sítio - Santos e Cheliz, 2017) teria constituído um atrativo para a ocupação humana pretérita e fonte secundária de matéria-prima para lascamento, em alternativa a afloramentos rochosos, que são escassos no contexto regional. Simultaneamente, porém, existe dúvida sobre a origem das peças, se ligada a exposição da cascalheira basal na fase I, ou se relacionada a eventuais novas exposições de segmentos da cascalheira durante a erosão intensa da fase III. Isto se deve sobretudo ao fato de, até o momento, apenas uma idade isolada no perfil UE1-2010 (14500+-3000 anos) ter sido obtida a partir de níveis arqueológicos da cascalheira basal, e com margem de erro mais ampla de que as demais.

Em suma, os dados aqui apresentados reforçam a caracterização de um intervalo de umidade menor que o atual em ao menos parte do tempo compreendido entre $14500+-3000$ e 10900+-1160 anos atrás, associado às cascalheiras basais das UEs e à fase I de formação da paisagem local; ele teria se sucedido de um intervalo de aumento da umidade, associado à gênese das porções mais profundas das coberturas superficiais areno-argilosas dos Baixos Terraços, na fase II de formação da paisagem, de maneira similar ao já apontado por Cheliz (2010, 2011, 2012, 20132015 e 2016) e Cheliz e Oliveira (2011 e 2019). As diferenças observadas na largura do paleocanal do meandro abandonado do tipo I (quatro vezes mais largo que o canal atual) no topo dos Baixos Terraços IIa, cuja gênese está associada à fase II da paisagem local, e as do meandros abandonados do tipo II (semelhantes às do canal atual do Jacaré-Guaçu), vinculados à fase III, também permitem sugerir mudanças ambientais, possivelmente ligadas respectivamente a variações de umidade e precipitação e à transição para os padrões climáticos atualmente predominantes na área. Nota-se semelhança das interpretações paleoambientais aqui sugeridas com as de Turcq et al. (1997), sobre a paleo-hidrologia de área próxima ao limite entre as Cuestas e o Planalto Ocidental Paulista (sensu Almeida, 1964), que apontam um intervalo mais seco do que o atual entre 17000 e 10000 anos atrás, seguido de um intervalo de maior umidade.

\section{Considerações finais}

Aprofundou-se a caracterização de um conjunto de transformações geomorfológicas, hidrológicas e pedológicas ocorridas desde a transição Pleistoceno-Holoceno em um segmento da planície aluvial e dos baixos terraços do rio Jacaré-Guaçu. Estas transformações foram concomitantes com a passagem de condições climáticas mais secas, no Pleistoceno Tardio (fase I), para mais úmidas e com elevação do lençol freático, no Holoceno Inicial, a partir de 10900+1,2 mil anos atrás (fases II e III). Alternaram-se intervalos de estabilidade ligados ao desenvolvimento de paleossolos, e outros de ascensão (fase II) ou redução (fase III) do nível de base local e da própria altitude $(<7 \mathrm{~m})$ do rio Jacaré-Guaçu; modificações ocorreram também nos padrões hidrológicos e morfológicos do sistema fluvial, incluindo passagem de canais torrenciais efêmeros (fase I) para canais perenes meandrantes quatro vezes mais largos que o atual rio Jacaré-Guaçu (fase II), e posterior diminuição das dimensões planimétricas de tais canais perenes, que se deu concomitantemente a significativo deslocamento horizontal, da ordem de $600 \mathrm{~m}$, no curso do rio. Registra-se, ainda, rebaixamento pronunciado do lençol freático local após a deposição dos sedimentos da fase II, potencialmente ligado a intervalos de clima mais seco que o atual ao longo do Holoceno. Ao menos uma parte destas mudanças físico-ambientais deuse simultaneamente à ocupação humana na área por grupos de caçadores-coletores que interagiram e, por vezes, tiraram proveito delas; um exemplo disso é o uso de cascalheiras de canais fluviais pleistocênicos como matérias-primas para a confecção de parte de seus artefatos.

Um maior aprofundamento do conhecimento sobre as transformações ambientais correlatas à gênese dos Baixos Terraços poderá ser conseguido através de: melhor caracterização da estrutura superficial local, por meio da realização de novas unidades de escavação; investigações de detalhe da fração argila dos horizontes de solo, com uso de microscópico eletrônico de varredura; e obtenção de novas idades absolutas, de modo a detalhar a cronologia das discordâncias e oscilações ambientais já identificadas (em especial, aquelas das fases II e III de formação da paisagem local).

No âmbito do detalhamento dos efeitos da ascensão e rebaixamento de nível de base e do rio Jacaré-Guaçu na paisagem, o adensamento da caracterização dos materiais arqueológicos presentes em meio às coberturas areno-argilosas e no topo da cascalheira poderá contribuir para verificar sua consistência enquanto indicadores de paleossuperfícies formadas no decorrer da 
evolução geomorfológica. Poderá também trazer elementos adicionais para a discussão de se os processos de ascensão do nível de base da fase II e de rebaixamento do nível do base da fase III foram ou não predominantemente lineares $\mathrm{e}$ uniformes.

\section{Agradecimentos}

Agradecemos ao $\mathrm{CNPq}$ pela concessão de bolsa de doutorado pleno ao primeiro autor (processo número 140496/2017-3) e de bolsa de produtividade em pesquisa ao segundo autor (processo número 308772/2018-0). Agradecemos e realizamos uma homenagem póstuma ao aviador araraquarense André Amaral, que gentilmente autorizou o uso de sua fotografia no presente trabalho de pesquisa. Agradecemos também: a Astolfo Araujo, Edilson Freitas, Francisco Ladeira, Fabio Grossi dos Santos, James Feathers, Maria Helena, Ricardo Bastos e Robson Rodrigues, pelo trabalho colaborativo efetuado nas intervenções na área de estudo; a todo o grupo de voluntários da Fundação Araporã, bem como a Daniele Lopes e Marcelo Delillo, pelo apoio ao levantamento de dados de campo; ao projeto Paleoíndio Paulista, da FAPESP (número de processo 13/13794-5), coordenado por Astolfo Araujo, pelo apoio material em parte das atividades de aquisição dos dados de campo analisados no presente artigo; e ao IPHAN, pela concessão de portarias de pesquisa (nos nomes de Astolfo Araujo, Fabio Grossi dos Santos e Robson Rodrigues) que autorizaram as diversas etapas de campo nas quais os dados trabalhados no presente artigo foram obtidos.

\section{Referências}

Ab`Saber, A.N., 1969. Um conceito de geomorfologia a serviço das pesquisas sobre o Quaternário. Geomorfologia 18, 1-23.

Ab`Saber, A.N., 1998. Participação das depressões periféricas e superfícies aplainadas na compartimentação do Planalto Brasileiro. Revista do Instituto Geológico 19, 51-69.

Almeida, F.F.M., 1964. Fundamentos geológicos do relevo paulista. Boletim do Instituto Geográfico e Geológico 41, 69-263.

Araujo, A.G.M.; Neves, W.A.; Piló, L B.; Atui J. P., 2005. Holocene dryness and human occupation in Brazil during the "Archaic Gap". Quaternary Research. 64, 298-307.

Aviles, A.M.; Ricardi-Branco, F.; Ledru, M., Bernacci, L.C., 2019. Vegetation and climate changes in the forest of Campinas, São Paulo
State, Brazil, during the last 25,000 cal yr BP. Brazilian Journal of Geology, 49, 1-11. DOI: $\quad$ https://doi.org/10.1590/23174889201920190040

Barros, L.F.P; Reis, R.A.P., 2019. A produção científica em geomorfologia fluvial na Revista Brasileira de Geomorfologia: panorama bibliográfico, tendências e lacunas. Revista Brasileira de Geomorfologia 20, 673-680. DOI: http://dx.doi.org/10.20502/rbg.v20i3.1553

Bernal, J.P.; Cruz, F.W.; Strikis, N.M.; Wang, X.; Deinnger, M.; Catunda, M.C.A.; OrtegaObregón, C.; Cheng, H.; Edwards, R.L.; Auler, A.S., 2016. High-resolution Holocene South American Monsoon history recorded by a speleothem from Botuverá cave, Brazil. Earth and Planetary Science Letters 450: 186-196.

Bull, W., 1990. Stream-terrace genesis: implications for soil development. Geomorphology, 3, p 351-367. Doi: https://doi.org/10.1016/0169555X(90)90011-E

Caetano-Chang, M.R.C. e Wu, F.T., 2006. Arenitos flúvio-eólicos da porção superior da Formação Pirambóia no centro-leste paulista. Revista Brasileira de Geociências 36, 294304. Disponível em: http://www.ppegeo.igc.usp.br/index.php/rbg/ article/view/9339. Acesso: 04 Jun. 2019.

Camargo, O.; Moniz; A.; Jorge, J; Valadares, J., 2009. Métodos de Análise Química, Mineralógica e Física de Solos do Instituto Agronômico de Campinas. Boletim Técnico 106. Instituto Agronômico de Campinas, Campinas.

Carvalho, A.; Magalhões Junior, A.P., 2018. O papel dos processos fluviais na configuração de fundos de vale na Bacia do Rio Paraúba Serra do Espinhaço Meridional, Sudeste do Brasil Revista Brasileira de Geomorfologia 19, 691-708. DOI: http://dx.doi.org/10.20502/rbg.v19i4.1354

Castro, S. e Cooper, M., 2019. Fundamentos de micromorfologia de solos, 1 ed. SBCS, Viçosa.

Celarino, A., 2011. Análise cronológica e pedológica de uma topossequência na Estação Ecológica de Jataí, Luis Antonio SP: Relação entre processos pedogenéticos na vertente e na planície aluvial do rio Mogi Guaçu. Tese (dissertação). Campinas, IGUNICAMP.

Celarino, A., 2015. O Quaternário Tardio na bacia do rio Pardo (MG e $\mathrm{SP}$ ): analíses 
morfométricas e evidências paleoambientais preservadas em solos e sedimentos de planícies fluviais. Tese (doutorado). Campinas, IG-UNICAMP.

Cheliz, P.M., 2011. Implicações quaternárias da geomorfogênese de um segmento das cuestas basálticas: Aspectos geomorfológicos e arqueológicos. In: Anais do XIII Congresso da Associação Brasileira de Estudos do Quaternário ABEQUA. III Encontro do Quaternário Sulamericano. XIII ABEQUA Congress - The South American Quaternary: Challenges and Perspectives. ABEQUA, Buzius.

Disponível: http://www.abequa.org.br/diretoria.php Acesso: 04 jun, 2020.

Cheliz, P.M., 2012a. Compartimentos ambientais, paleoambientes e ocupação humana pretérita: as terras baixas do Jacaré-Guaçu. Espaço Científico Livre, 14-27.

Cheliz, P.M., 2012b. Dinâmica fluvial Quaternária e influência estrutural no modelado do relevo: Ponderações a partir das cuestas concêntricas. In: Anais do I Congresso de Geologia dos Países de Língua Portuguesa / 46 Congresso Brasileiro de Geologia. Sociedade Brasileia de Geologia, Santos. Disponível:

http://www.sbgeo.org.br/home/pages/44 Acesso: 04 Jun. 2019

Cheliz, P.M., 2013a. Bases físico-ambientais da pesquisa arqueológica: o Estado de São Paulo. Revista Do Museu De Arqueologia E Etnologia, 23, 49-60. DOI: https://doi.org/10.11606/issn.24481750.revmae.2013.106835

Cheliz, P.M., 2013b. Quadros ambientais e ocupação humana pretérita: bases físicas da pesquisa arqueológica em Araraquara. Disponível :https://www.researchgate.net/publication/33 7324327_Quadros_Ambientais_E_Ocupacao _Humana_Preterita_Bases_Fisicas_Da_Pesq uisa_Arqueologica_Em_Araraquara__Relatorio_Final_das_Atividades_Desenvolv idas_no_MAPA_Museu_de_Arqueologia_e_ Paleontologia_de_Arara Acesso em 04-062019

Cheliz, P.M., 2015. Interface entre quadros de relevo cuestiformes e registros arqueológicos líticos: cercanias de Araraquara, nordeste paulista, São Paulo, Brasil. Meridiano Revista de Geografía 4, 135-160.

Cheliz, P.M., 2016, Aspectos geomorfológicos da antiga Araraquara, com ênfase em subsídios para interface entre quadros de relevo e sítios arqueológicos líticos. Tese (monografia). Campinas, IG-UNICAMP.

Cheliz, P.M.; Ladeira, F.S.B., 2017. Contextualização de aspectos geomorfológicos e da cobertura superficial do Sítio Boa Esperança II (interior paulista), como subsídio para a discussão de sua antiguidade. In: Os Desafios da Geografia Física na Fronteira do Conhecimento. IGUNICAMP, Campinas. DOI: 10.20396/sbgfa.v1i2017.2530

Cheliz, P.M.; Ladeira, F.S.B.; Araujo, A.; Santos, F.G.; Rodrigues, R.; Oliveira; R.C.; Feathers, J., 2018. Interface entre quadros de relevo, flutuações ambientais e sítios arqueológicos líticos da Antiga Araraquara (interior de SP), com enfoque em parcela das Terras Baixas do Jacaré-Guaçu (sítio BES II). In: Anais do 49o Congresso Brasileiro de Geologia. Disponível:

http://cbg2018anais.siteoficial.ws/anexos/st7/ 9177.pdf Acessado em 04 jun. 2020.

Cheliz, P.M.; Moreno de Sousa, J.; Mingatos, G.; Okumura, M.; Araujo, A.; 2020. A ocupação humana antiga (11-7 mil anos atrás) do Planalto Meridional Brasileiro: caracterização geomorfológica, geológica, paleoclimática e tecnológica de sítios arqueológicos relacionados a três distintas indústrias líticas. Revista Brasileira de Geografia Física $13 . \quad$ Doi: 10.26848/rbgf.v13.5.p\%p

Cheliz, P.M.; Oliveira, R.C., 2011. A antiguidade da presença humana em São Paulo: uma discussão interdisciplinar. In: Anais do Congresso Interno do Programa Institucional de Iniciação Científica da UNICAMP. UNICAMP, Campinas.

Cheliz, P.M; Oliveira, R.C., 2019. Landscape formation, environmental changes and prehistoric occupation (Jacaré-Guaçu river Lowlands, Araraquara Area, Southeast Brazil, Late Pleistocene-Holocene interval): correlation between geomorphological, pedological, geochronological and archaeological data. Quaternary and Environmental Geosciences 10, 44-61. DOI: http://dx.doi.org/10.5380/abequa.v10i1.5759 4

Cruz, F.W.; Burns, S.J.; Karmann, I.; Sharp, W.D.; Vuille, M.; Cardoso, A.O.; Ferrari, J.A.; Silva Dias, P.L.; Viana Jr. O.; 2005. Insolation-driven changes in tmospheric circulation over the past 116 ky in subtropical Brazil. Nature 434, 63-66. DOI: 10.1038/nature03365 
Cruz, F.W.; Burns, S.J.; Karmann, I.; Sharp, W.D.; Vuille, M., 2006. Reconstruction of regional atmospheric circulation features during the late Pleistocene in subtropical Brazil from oxygen isotope composition of speleothems. Earth and Planetary Science Letters 248, 494-506.

Cunha, P., Cura, S., Cunha Ribeiro, J., Figueiredo, S., Martins, A., Raposo, L., Pereira, T., \& Almeida, N., 2017. The Lower and Middle Palaeolithic industries associated with the T4 Terrace of the Lower Tejo River (Central Portugal); Archives of the earliest human occupation on western Iberia, during ca. 340 ka to $155 \mathrm{ka}$ ago Journal of Lithic Studies, 4, $27-56$

DOI: https://doi.org/10.2218/jls.v4i3.2531

Cunha, P.P.; Martins, A.A.; Buylaert, J.-P.; Murray, A.S.; Gouveia, M.P.; Font, E.; Pereira, T.; Figueiredo, S.; Ferreira, C.; Bridgland, D.R.; Yang, P.; Stevaux, J.C.; Mota, R., 2019 The Lowermost Tejo River Terrace at Foz do Enxarrique, Portugal: A Palaeoenvironmental Archive from c. 60-35 $\mathrm{ka}$ and Its Implications for the Last Neanderthals in Westernmost Iberia. Quaternary 2, 1-30. DOI: 10.3390/quat2010003

Dunnell, R.C.; Stein, J.K., 1989 Theoretical Issues in the Interpretation of microartefacts. Geoarchaeology: An International Journal 4, 31-42.

DOI: https://doi.org/10.1002/gea.3340040103

Dias, R., 2015. Geocronologia da cobertura superficial em níveis geomorfológicos do setor centro-ocidental na Depressão Periférica Paulista. Tese (doutorado). Campinas, IG-UNICAMP.

EMBRAPA, 2006. Sistema brasileiro de classificação de solos. $2^{\mathrm{a}}$ Edição. Brasília: Embrapa Produção de Informação; Rio de Janeiro: Embrapa Solos, 306p.

Gesicki, A.L.D., 2007. Evolução diagenéticas das formações Piramboia e Botucatu (Sistema Aquífero Guarani) no Estado de São Paulo. Tese (doutorado). São Paulo, Instituto de Geociências, USP.

Giannini, P.C.F.; Sawakuchi, A.O.; Fernandes, L.A.; Donatti, L.M., 2004. Paleoventos e paleocorrentes subaquosas do Sistema Deposicional Pirambóia nos estados de São Paulo e Paraná, Bacia do Paraná: estudo baseado em análise estatística de dados azimutais. São Paulo, Revista Brasileira de Geociências 34, 282-292.
Goudie, A. 2013. Arid and Semi-Arid Geomorphology. Cambridge University Press.

Doi: https://doi.org/10.1017/CBO9780511794 261

Hazelwood, K.T.; Stetler, L.D., 2019. New insights into the fluvial geomorphology and its effects on paleofloods in the Black Hills, South Dakota, Geomorphology 327,80-92. DOI: https://doi.org/10.1016/j.geomorph.2018.10. 017

Hossain, S.; Imranuzzaman, M., 2019. Identification of the architecture and evolution of fluvial system using seismic geomorphology: A case study from Gulf of Thailand, Journal of Natural Gas Geoscience 4, 29-46. DOI: https://doi.org/10.1016/j.jnggs.2019.02.001.

IGC, 2020. Compilação e integração digital das cartas topográficas em escala 1:10000 para o Estado de São Paulo. Disponível: http://datageo.ambiente.sp.gov.br/app/\# Acesso: 05 Jun. 2020.

Kemp, J; Pietsch, T.; Gontz, A.; Olley, J., 2017. Lacustrine-fluvial interactions in Australia's Riverine Plains. Quaternary Science Reviews 166, 352-362. DOI: https://doi.org/10.1016/j.quascirev.2017.02.0 15.

Krynine, P., 1950. Petrology, stratigraphy, and origin of the Triassic sedimentary rocks of Connecticut. Tese (doutorado). New Haven, Yale University.

Lima, K. C.; Lipinacci, C. M., 2019 Morfologias fluviais em ambiente semiárido: questões teóricas aplicas a um estudo de caso. Revista Brasileira de Geomorfologia 20, 475-490. DOI: http://dx.doi.org/10.20502/rbg.v20i3.1597

Lupinacci, C.; Souza, T., 2019. Terraços fluviais como indicadores da dinâmica geomorfológico no Quaternário: estudo de caso na Depressão Periférica Paulista. Revista Brasileira de Geomorfologia 20, 427-444.

DOI: http://dx.doi.org/10.20502/rbg.v20i2.

Meaulo, F., 2007. Caracterização geológica, hidrogeológica e o mapeamento da vulnerabilidade natural à poluição dos aqüíferos, na escala 1:25.000, das áreas urbana e de expansão do município de Araraquara-SP. Tese (doutorado). Rio Claro, IG-UNESP.

Meira, F.C.; Stevaux, J.C.; Torrado, P.V.; Assine, M.L., 2019. Compartimentação e evolução 
geomorfológica da Planície do rio Cuiabá, Pantanal Mato-grossense. Revista Brasileira de Geomorfologia 20, 159-183. DOI: http://dx.doi.org/10.20502/rbg.v20i1.1444

Merino, E.; Assine, M.; Pupim, F., 2013. Estilos fluviais e evidências de mudanças ambientais na planície do rio Miranda, Pantanal. Revista Brasileira de Geomorfologia 14, 127-134. DOI:

http://dx.doi.org/10.20502/rbg.v14i2.246

Macedo, H.A.; Assine, M.L., Pupim, F.M., Merino, E.R.; Stevaux, J.C.; Silva, A., 2014. Mudanças Paleo-Hidrológicas Na Planície Do Rio Paraguai, Quaternário Do Pantanal. Revista Brasileira de Geomorfologia 15, 7585.

DOI: http://dx.doi.org/10.20502/rbg.v15i1.431

Oliveira, S.; Pupin, F.; Stevaux, J.; Assine, M., 2019. Luminescence Chronology of Terrace Development in the Upper Paraná River, Southeast Brazil. Frontiers in Earth Science 7, 1-17. DOI: https://doi.org/10.3389/feart.2019.00200

Passos, M.S.; Soares, E.; Tatumi, S.T., Yee, M.; Mittani, J.C.R.; Hayakawa, E.H.; Salazar, C.A., 2020. Pleistocene-Holocene sedimentary deposits of the SolimõesAmazonas fluvial system, Western Amazonia. Journal of South American Earth Sciences 98. DOI: https://doi.org/10.1016/j.jsames.2019.102455

Peña-Monné, J.K.; Sampietro-Vattuone, M.M.; Longares-Aladrén, L.A.; Pérez-Lambán, F.; Sánchez-Fabre, M.; Alcolea-Gracia, M.; Vallés, L.; Echeverría-Arnedo, M.T.; Baraza, C., 2018. Holocene Alluvial Sequence In The Val De Zaragoza (Los Monegros) In The Palaeoenvironmental Context Of The Ebro Basin (NE Spain). Cuadernos de Investigación Geográfica 44, 1-17. DOI: http://doi.org/10.18172/cig.3358. PP 321-348

Penteado M., 1976. Geomorfologia do Setor Centro-Ocidental da Depressão Periférica Paulista. Tese (doutorado). São Paulo, IGUSP.

Pupim, F.N.; Sawakuchi, A.O.; Almeida, R.P.; Ribas, C.C.; Kern, A.K., Hartmann, G.A.; Chiessi, C.M.; Tamura, L.N.; Mineli, T.D.; Savian, J.F.; Grohmann, C.H.; Bertassoli, D.J.; Stern, A.G; Cruz, F.W.; Cracraft, J., 2019. Chronology of Terra Firme formation in Amazonian lowlands reveals a dynamic Quaternary landscape. Quaternary Science Reviews 210, 154-163. DOI: https://doi.org/10.1016/j.quascirev.2019.03.0 08
Qi'an, M; Shun, Z; Guoxin, S; Xiuli, F; Chao, W; Yao, S., 2016. A seismic geomorphology study of the fluvial and lacustrine-delta facies of the Cretaceous Quantou-Nenjiang Formations in Songliao Basin, China, Marine and Petroleum Geology 78, 836-847. DOI: https://doi.org/10.1016/j.marpetgeo.2016.01. $\underline{017}$

Ricci, O., 2018. Microartefatos e análise geoarqueológica: um estudo de caso da região de Rio Claro - SP. Dissertação (mestrado). São Paulo, Museu de Arqueologia e Etnologia-USP.

Santos, F.G., 2011. Sítios líticos do interior paulista: Um enfoque regional. Tese (mestrado). São Paulo, Museu de Arqueologia e Etnologia-USP.

Santos, F.G., 2013. Abordagem teórica sobre o estudo de sítios líticos no interior do estado de São Paulo, Brasil. Techné, 1, 39-49.

Santos, F.G. e Cheliz, P.M., 2017. Aspectos do Sítio Lítico Boa Esperança II (interior paulista), ponderados pela interface com quadros geomórficos regionais e sua possível inserção no contexto da transição Pleistoceno-Holoceno. Cadernos do Lepaarq 14, 435-457. DOI: http://dx.doi.org/10.15210/lepaarq.v14i27.10 $\underline{144}$

Santos, F.; Cheliz, P.M., 2019. The huntergatherer site BES II (Jacaré-Guaçu River low terraces, central Sao Paulo state, Brazil): Interface with geomorphical and environmental fluctuations of the Pleistocene-Holocene transition. Journal of Lithic Studies, 6, 25. https://doi.org/10.2218/jls.2783

Souza, M.M., 2010, Palinologia em sedimentos quaternários, localizados na Estação do Instituto Florestal de Jataí, SP. Tese (mestrado). Campinas, IG-UNICAMP

Stríkis, N.M.; Cruz, F.W.; Cheng, H.; Karmann, I.; Edwards, R.L.; Vuille, M.; Wang, X.; Paula, M.S.; Novello, V.F.; Auler, A.S., 2011. Abrupt variations in South American monsoon rainfall during the Holocene based on a speleothem record from central-eastern Brazil. Geology, 39: 1075-1078.

Turcq, B.; Pressinotti, M. M. N.; Martin, L., 1997. Paleohydrology and paleoclimate of the Past 33,000 years at the Tamanduá River, Central Brazil. Quaternary Research, 47, 284-294. https://doi.org/10.1006/qres.1997.1880

Veneziani, Y. e Rodrigues, C., 2019 Geomorfologia fluvial do Baixo Ribeira do 
Revista Brasileira de Geografia Física, Vol. 13, n. 05 (2020) 1970-1993.

Iguape, São Paulo, Brasil. Revista Brasileira de Geomorfologia 20, 541-562 DOI: http://dx.doi.org/10.20502/rbg.v20i3.1545

Zanettini Arqueologia, 2003. Relatório final do Programa Arqueológico Gasoduto
Araraquara / Norte - Trecho Boa Esperança do Sul - Araraquara, estado de São Paulo. Relatório técnico de licenciamento ambiental, não publicado. 